Chapter 3

\title{
Evolutionary Origin and Adaptive Function of Meiosis
}

\author{
Harris Bernstein and Carol Bernstein \\ Additional information is available at the end of the chapter \\ http://dx.doi.org/10.5772/56557
}

\section{Introduction}

The origin of meiosis and its adaptive function in eukaryotes, and the related problem of the origin and adaptive function of sex in eukaryotes, are fundamental issues in biology. Among eukaryotes, meiosis and sexual reproduction are widespread, occurring in single-celled eukaryotes (including protozoans such as paramecium), and fungi (e.g. yeast) and in most multicellular organisms including animals and most plants. Accumulating evidence indicates that meiosis arose very early in the evolution of eukaryotes (reviewed in Bernstein \& Bernstein, 2010). Thus, basic features of meiosis were likely already present in the prokaryotic ancestors of eukaryotes.

Central features of meiosis are the pairing of homologous chromosomes of different parental origin, recombination (information exchange) between these chromosomes, and the passage of the recombined chromosomes to progeny. In bacteria, the sexual process of transformation has these same essential features (Michod et al., 2008). In a further parallel, key enzymes that catalyze meiotic recombination are homologous to enzymes that serve similar functions in the recombinational steps of transformation. The earliest eukaryotic organisms were single-celled protists, similar to bacteria. In this chapter we review the evidence that meiosis in the earliest single-celled eukaryotes evolved from the sexual process of transformation in their bacterial ancestors.

Among extant organisms, both single-celled bacteria and single-celled eukaryotes tend to enter the sexual cycle under conditions of environmental stress (Bernstein \& Bernstein, 2010). These are conditions that can cause DNA damage. DNA damage appears to be an important fundamental problem for all organisms. We review evidence here that DNA damaging agents induce sex in prokaryotes and microbial eukaryotes. We summarize evidence in bacterial transformation and in eukaryotic meiosis that recombination serves the adaptive function of 
removing DNA damages that are potentially lethal to progeny (see also Bernstein \& Bernstein, 2004; Bernstein et al., 2011).

Thus in this chapter we explore the reasoned likelihood that meiotic recombination arose from bacterial transformation and that both transformation and meiosis are adaptations for repairing damage in the DNA to be passed on to progeny.

\section{The common ancestor of all eukaryotes was likely capable of meiosis}

Eukaryotes emerged from prokaryotic ancestors more than 1.5 billion years ago (Javaux et al., 2001). The oldest taxonomically resolved eukaryote in the fossil record, Bangiomorph pubescens, a red algae, existed more than 1.2 billion years ago and was sexually reproducing (Butterfield, 2000). Although meiotic sex is widespread among extant eukaryotes, it has, until recently, been unclear whether or not eukaryotes were sexual early in their evolution. The reason for this uncertainty was that sexual reproduction and meiosis appeared to be absent in certain eukaryotes thought to belong to lineages that diverged early in eukaryote evolution. However, due to recent advances in gene detection and other techniques, an increasing number of the presumed "ancient asexual" eukaryotes are now known to be capable of, or to recently have had the capacity, to undergo meiosis and hence sexual reproduction.

Thus, the common intestinal parasite Giardia intestinalis was once thought to be an asexual descendant of a eukaryotic lineage that arose prior to the emergence of meiosis and sex, but it was recently found to have a core set of meiotic genes, including five genes known to be specific to meiosis (Ramash et al., 2005). Evidence indicative of current sexual reproduction in present day Giardia intestinalis has now also been found (Cooper et al., 2007). In another example, a sexual cycle was recently found in parasitic protozoa of the genus Leishmania (Akopyants et al., 2009).

Trichomonas vaginalis is a unicellular parasitic eukaryote. Although not known to currently undergo meiosis, this capability was likely present in a recent ancestor of this organism. This conclusion is based on the work of Malik et al. (2008) who tested Trichomonas vaginalis for the presence of 29 genes involved in meiosis and found 27 of these meiosis genes to be present, including 8 of 9 genes specific to meiosis in model organisms. Of the 27 meiotic genes that were present in Trichomonas vaginalis, 21 were also present in Giardia intestinalis. This finding indicates that most of the meiotic genes were present in a common ancestor of these two species. Since these species are descendants of separate lineages that diverged very early in the evolution of eukaryotes, Malik et al. (2008) suggested that each of the genes held in common was present in the common ancestor of all eukaryotes. Dacks and Roger (1999) also proposed, on the basis of a phylogenetic analysis, that facultative sex was present in the common ancestor of all eukaryotes. Lahr et al. (2011) recently reported evidence from a study of amoebae that supports this view. Even though amoebae are conventionally considered to be asexual, these authors presented evidence that most amoeboid lineages were at one time sexual, and that most asexual groups probably arose recently and independently. 
Another group of eukaryotes, commonly referred to as a member of the "ancient asexuals," the arbuscular mycorrhizal fungi, were thought to have propagated colonally for over 500 million years. However, recently, several members of this group (Glomus spp.) were shown to possess in their genome homologs of 51 meiotic genes including seven meiosis-specific genes, suggesting that their meiotic machinery has been conserved (Halary et al., 2011). The pathogenic yeast Candida albicans had been long regarded as an "asexual" eukaryote. However, it is now known that this organism has maintained an elaborate-but largely hidden-mating apparatus (Johnson, 2003).

Thus, the common ancestor of current day eukaryotes was likely capable of meiosis.

\section{Natural bacterial transformation as a form of sex}

Natural bacterial transformation involves the transfer of DNA from one bacterium to another through the surrounding medium. Transformation depends on the expression of numerous bacterial genes whose products appear to be designed to carry out this process (Chen and Dubnau, 2004; Johnsborg et al., 2007). Transformation is ordinarily a complex, energy requiring developmental process. In order for a bacterium to bind, take up and recombine exogenous DNA into its chromosome it must enter a special physiological state, referred to as competence. Development of competence in Bacillus subtilis requires expression of about 40 genes (Solomon and Grossman, 1996). The exogenous DNA integrated into the recipient chromosome is usually (with rare exceptions) derived from another bacterium of the same species, and is thus homologous to the resident chromosome. The amount of DNA transferred during transformation can be a large portion, or the full length, of the bacterial chromosome (Akamatsu and Taguchi, 2001; Saito et al., 2006). The capacity for natural transformation appears to be common in nature, and thus far 67 prokaryotic species (in seven different phyla) are known to undergo this process (Johnsborg et al., 2007). As understanding of the behavior of other bacterial species under crowded conditions, such as in biofilms, continues to advance, many further examples of transformation are likely to be discovered. Transformation in bacteria can be viewed as a primitive sexual process, since it involves interaction of homologous DNA from two individuals to form recombinant DNA that is passed on to succeeding generations.

Transformation is similar to eukaryotic sex involving hydrophilus pollination in plants, in which water is a vector in the transportation of pollen (Cox, 1988). In both bacterial transformation and sex in such plants, DNA is passed from one individual to another through the intervening liquid medium, rather than by direct contact. On the other hand, an intermediate stage in the evolution of prokaryotic to eukaryotic sex may have been similar to sexual interaction in the extant archaebacterium Halobacterium volcanii that involves direct contact, similar to sexual interaction in paramecium and yeast. Halobacterium volcanii have a distinctive mating system in which cytoplasmic bridges between cells appear to be used for transfer of DNA from one cell to another in either direction (Rosenshine et al., 1989). In another similar bacterial system involving direct contact, Frols et al. (2008) showed that exposure of the archaebacterium Sulfolobus solfataricus to the DNA damaging agents UV-irradiation, bleomy- 
cin or mitomycin $\mathrm{C}$ induced cellular aggregation. Aggregation was not inducible by other physical stressors, such as $\mathrm{pH}$ or temperature shift, suggesting that induction is caused specifically by DNA damage. Frols et al. $(2008 ; 2009)$ hypothesized that cellular aggregation enhances DNA transfer among Sulfolobus cells to provide increased repair of damaged DNA via homologous recombination. In related work, Wood et al. (1997) found that UV-irradiation of the thermophilic archaebacterium Sulfolobus acidocaldarius increased the frequency of recombination due to genetic exchange.

The transformation systems and archaebacterial systems appear to differ fundamentally from the more well-studied E. coli conjugation that is mediated by a parasitic plasmid (F-factor). In the bacterial transformation systems and archaebacterial systems, the genes promoting the sexual process of DNA transfer are presumably encoded in the bacterial genome, while for conjugation in E. coli, the genes governing conjugation are encoded in the parasitic plasmid.

\section{Transformation and meiosis are similar at a molecular level}

Bacterial transformation and eukaryotic meiosis are similar in their central molecular processes, and these processes are catalyzed by homologous gene products. There are three major steps in bacterial transformation: (1) DNA derived from a donor cell enters into a recipient cell; (2) the two homologous chromosomes (or homologous portions of the two chromosomes) derived from the two bacterial cells align and undergo genetic recombination (exchange of genetic information); (3) the new recombined chromosome is passed on to progeny bacteria. Meiosis in diploid eukaryotic cells can similarly be viewed as occurring by three steps. These steps are: (1) gametes undergo syngamy/fertilization so that chromosomes of different cellular origin share the same nucleus; (2) homologous chromosomes from different cells (i.e. nonsister chromosomes) align in pairs and undergo recombination; (3) two successive cell divisions (without chromosome duplication) lead to haploid gametes, which can repeat the cycle in subsequent generations. In meiosis, as in transformation, the central step (step 2) is the intimate alignment of non-sister homologous chromosomes followed by genetic recombination. In bacteria, recombination between non-sister homologous chromosomes is catalyzed by the RecA protein, and in eukaryotes this same reaction is catalyzed by orthologs of RecA, such as Rad51 and Dmc1 (see section 16, below).

\section{The prokaryotic ancestor of eukaryotes was likely capable of transformation}

The hypothesis that meiosis evolved from transformation depends on the assumption that the prokaryotic ancestor of the eukaryotic cell lineage was able to undergo transformation. A crucial event in the emergence of the eukaryotic cell was likely the establishment of a stable association of an anaerobic host bacterium and a smaller, internalized aerobic bacterium. We next consider the likelihood that this progenitor of the eukaryotic cell lineage was capable of 
transformation. The internalized aerobic bacterium is assumed to have provided the capacity for respiration, and to have eventually evolved into the mitochondrion. We will first focus on the nature of the internalized aerobe, and then on its anaerobic host.

On the basis of genome sequence analysis, extant mitochondria are most closely related to $\alpha$ proteobacteria, suggesting that mitochondria are descended from an $\alpha$-proteobacterium (Gray et al., 1999; Muller and Martin, 1999). Based on a computational analysis, Boussau et al. (2004) concluded that the common ancestor of $\alpha$-proteobacteria likely had a genome consisting of between 3000 and 5000 genes, and was an aerobic, motile bacterium with pili and surface proteins for interacting with host cells. A gene sequence data analysis by Gray et al. (1999) strongly indicated a monophyletic origin of mitochondria from an $\alpha$-proteobacterial ancestor, and also implied that mitochondria evolved only once. We can assess the plausibility of the idea that such an ancestor was capable of transformation by knowing whether present day $\alpha$ proteobacteria are capable of transformation. In fact, several present day $\alpha$-proteobacteria are capable of natural transformation, including Agrobacterium tumefaciens (Demaneche et al., 2001), Methylobacterium organophilum (O'Connor et al., 1977) and Bradyrhizobium japonicum (Raina and Modi, 1972).

The ancient anaerobic bacterial host of the internalized proto-mitochondrion was determined on the basis of a phylogenetic analysis to likely be an archaebacterium (Cox et al., 2008). Transformation has been reported among currently living archaebacteria including Methanococcus voltae (Bertani and Baresi, 1987; Patel et al., 1994), Methanobacterium thermaautotrophicum (Worrell et al., 1988) and Halobacterium volcani (Cline et al., 1989). On the basis of the known transformation capabilities of extant bacteria, it is a reasonable possibility that when the eukaryotic lineage first emerged, presumably by the association of an archaebacterium and an $\alpha$-proteobacterium, at least one and possibly both of the partners were capable of transformation.

Evidence indicates that, during the evolution of mitochondria from an ancestral $\alpha$-proteobacterium, much of the genetic information of the $\alpha$-proteobacterium was transferred to, and became integrated into, the host nuclear genome. Phylogenetic studies by Gabaldon and Huynen (2003) suggest that at least 630 genes were transferred to the nuclear genome from the $\alpha$-proteobacterial genome. If the ancestral $\alpha$-proteobacterium was capable of transformation, as are some of its current day relatives, its genes necessary for transformation may have been integrated into the early eukaryotic nuclear genome. In current-day organisms, the gene family $\operatorname{Rec} A / \operatorname{Rad} 51 / D m c 1$ is central to the machinery of both bacterial transformation and meiotic recombination. The $\operatorname{Rec} A$ orthologs in eukaryotes have a high level of sequence similarity to $\operatorname{Rec} A$ genes from proteobacteria. Lin et al. (2006) suggested that transfer of the RecA gene from the early pre-mitochondria to the nuclear genome of ancestral eukaryotes could be the cause of this sequence similarity. Alternatively, recA-like genes from the archaebacterial ancestor may have given rise to the rad51/dmc1 genes of eukaryotes as suggested by the work of Sandler et al. (1996). Thus genes central to eukaryotic meiosis could have been derived from genes central to transformation in a prokaryote. In subsequent sections we will argue that the adaptive function of transformation in the early prokaryotic predecessors of eukaryotes and 
of meiosis in their eukaryotic descendents is repair of DNA damage. However, first we discuss evidence that DNA damage is an important fundamental difficulty with which life must cope.

\section{DNA damage is a basic problem for life}

A DNA damage is an alteration in the molecular structure of DNA, such as a break in one or both DNA strands, a missing base, or an oxidized base (e.g. 8-OHdG). Damage to DNA often results from natural processes. As noted by Haynes (1988), DNA is comprised of rather ordinary molecular subunits that are not endowed with any unusual quantum mechanical stability, and this "chemical vulgarity" makes DNA vulnerable to all the "chemical horrors" that might befall any such molecule in a warm aqueous environment. The particular types of DNA damage occurring when organisms were undergoing the prokaryotic to eucaryotic transition cannot be determined directly, but can be indirectly surmised from the types of DNA damage occurring in present day organisms. In extant cellular organisms, metabolism releases numerous compounds that damage DNA including reactive oxygen species, reactive nitrogen species, reactive carbonyl species, lipid peroxidation products and alkylating compounds, among others, while hydrolysis cleaves chemical bonds in DNA (De Bont and van Larebeke, 2004). In eukaryotes such as mammals, tens to hundreds of thousands of naturally caused DNA damages occur per cell per day (see next section). While most of these DNA damages can be repaired, such repair is not $100 \%$ efficient. Unrepaired DNA damages accumulate, especially in non-replicating or slowly replicating cells.

One indication that DNA damages are a major problem for life is that DNA repair processes, to cope with ubiquitously occurring DNA damages, have been found in all cellular organisms in which DNA repair has been investigated. For example, in bacteria, a regulatory network aimed at repairing DNA damages (called the SOS response in Escherichia coli) has been found in many bacterial species. E. coli RecA, a key enzyme in the SOS response pathway, is the defining member of a ubiquitous class of DNA strand-exchange proteins that are essential for homologous recombinational repair, a pathway that maintains genomic integrity by repairing broken DNA (Bell et al., 2012). Eukaryotic recombinases that are homologues of RecA are also widespread in eukaryotes. For example, in fission yeast and humans, RecA homologues promote duplex-duplex DNA-strand exchange needed for repair of many types of DNA damages (Murayama et al., 2008; Holthausen et al., 2010).

Another indication that DNA damages are a major problem for life is that cells make large investments in DNA repair processes. As pointed out by Hoeijmakers (2009), repairing just one double-strand break may require more than 10,000 ATP molecules, since ATP is used in signaling the presence of the damage, the generation of repair foci, and the formation (in humans) of nucleofilament intermediates in homologous recombinational repair by RAD51, a homologue of bacterial RecA.

In plants, dormant seeds accumulate DNA damages which can be largely repaired during germination (Cheah and Osborne, 1978; Koppen and Verschaeve, 2001). Multiple effective 
pathways for DNA damage signalling and repair have evolved in plants for dealing with endogenous and exogenous sources of DNA damage (reviewed by Bray and West, 2005).

Sagan (1973) examined the flux of solar UV irradiation penetrating the primitive reducing atmosphere of earth prior to the formation of a shielding ozone layer, and concluded that a mean lethal dose would be delivered to unprotected microorganisms of the type existing today in 0.3 seconds or less. Since DNA damage is the main cause of UV-induced lethality, it appears that DNA damage was likely a problem for even the earliest microorganisms.

\section{Frequency of occurrence and consequences of DNA damage}

An idea of the magnitude of the biologic problem posed by naturally occuring DNA damage can be obtained by considering the frequency of occurrence and consequences of DNA damages in present day organisms. The estimated frequency of occurrence of oxidative DNA damages per cell per day is about 10,000 in humans (Ames et al., 1993; Helbock et al., 1998) and about 74,000 to 100,000 in rats (Fraga et al., 1990; Ames et al., 1993; Helbock et al., 1998). For depurinations, the estimated frequency is 9,000 to 13,920 , per mammalian cell per day (Nakamura et al., 1998; Tice and Setlow, 1985); for single-strand breaks, the frequency is about 55,200 per cell per day (Tice and Setlow, 1985). Double-strand breaks, which are difficult to repair accurately, occur in human cells at a frequency estimated to be 10 (Haber, 1999) to 50 (Vilenchik \& Knudson, 2003) per cell cycle. Other types of DNA damage, such as formation of $\mathrm{O}^{6}$-methylguanine and cytosine deamination are also frequent.

An unrepaired DNA damage may block replication of the DNA, and when such a damage occurs in the transcribed strand, it may also block RNA polymerase catalysed transcription (Kathe et al., 2004). Blockage of DNA replication can be lethal to a cell, and blockage of transcription is deleterious because it can interfere with the synthesis of a protein coded for by the gene in which a blockage occurs.

Also, during DNA replication, as the DNA polymerase copies a DNA strand containing a damaged site, it may inaccurately bypass the damage and in so doing generate a mutation. Although damages and mutations are both errors in DNA, DNA damages are distinct from mutations. DNA damages are structural and chemical alterations in the DNA, whereas mutations ordinarily involve the normal four bases in new arrangements. Furthemore, whereas DNA damages are altered structures that cannot be replicated, mutations can be replicated when the DNA replicates. In aerobically growing bacteria, reactive oxygen species (ROS) seem to be an important source of DNA damage, as indicated by the observation that $89 \%$ of spontaneously occurring base substitution mutations are caused by inaccurate replication past bases damaged by ROS (Sakai et al., 2006). Thus another harmful consequence of DNA damages is that they likely generate a substantial portion of spontaneous mutations.

Further consequences of DNA damages for eukaryotes and prokaryotes are the expenditures of energy, time and material resoures (e.g. nucleotides) required by the multiple processes that repair DNA damages. Five major pathways are employed in repairing various kinds of DNA 
damages. These processes are nucleotide excision repair, base excision repair, mismatch repair, non-homologous end joining and homologous recombinational repair (HRR) [reviewed in Bernstein et al. (2002)]. Only one of the five pathways, HRR, is able to accurately repair doublestrand damages, such as double-strand breaks (DSBs). The HRR pathway depends on the availability of second homologous chromosome for restoring the information lost by the first chromosome due to the DSB. As detailed below, in both prokaryotes and eukaryotes, sex promotes the conditions needed for especially effective HRR of double-strand damages.

Overall, it is clear that, in eukaryotes and prokaryotes, DNA damages are ubiquitous and thus are a major problem for cellular and organismal survival. Furthermore, over time, DNA damages have selected for the evolution of numerous complex, specialized DNA repair pathways.

\section{Competence for transformation is induced by stress in prokaryotes}

Both transformation and meiosis (in microbial eukaryotes) are induced by stressful conditions. Thus transformation may have evolved by natural selection as an adaptive response to stress in prokaryotes and been maintained for this purpose subsequent to the transition to meiotic sex. In this section we describe stressful conditions that induce competence for transformation and in section 10 we describe similar stressful conditions that induce meiotic sex in eukaryotic microorganisms.

Among present day bacteria, competence for transformation is induced when bacteria are grown to high cell density and/or under nutritional limitation, conditions characteristic of the stationary phase of bacterial growth. As an example, transformation in Haemophilus influenzae occurs most efficiently at the end of exponential growth as cells approach stationary phase (Goodgal and Herriott, 1961). In Streptococcus mutans, as well as many other streptococci, transformation occurs at high cell density, especially during biofilm formation (Aspiras et al., 2004). Competence in Bacillus subtilis is induced toward the end of logarithmic growth, particularly under conditions of amino acid limitation (Anagnostopoulos and Spizizen, 1961). Michod et al. (2008) reviewed evidence suggesting that, in the inflammatory oxidizing environment associated with infection, transformation in pathogenic bacteria (i.e. Neisseria gonorrhoeae, Haemophilus influenzae, Streptococcus pneumoniae, Streptococcus mutans and Helicobacter pylori) provides a substantial benefit by allowing repair of DNA damage.

As discussed above in section 3, certain archaebacteria, namely Halobacterium volcanii and Sulfolobus solfataricus, appear to have distinctive mating systems involving DNA transfer through direct contacts between cells. We suggested that such mating systems may represent an intermediate stage in the transition from prokaryotic transformation to eukaryotic sex. In agreement with this view, Gross and Bhattacharya (2010) proposed that eukaryotic meiosis arose from archael conjugation and that both processes serve the same purpose, repair of damage, particularly double-strand breaks. These authors also suggested a model for restructuring of the archael cell during premeiotic evolution. 


\section{The adaptive function of transformation is likely repair of stress-induced DNA damage}

Competence for transformation is induced specifically by DNA damaging conditions. For instance, the DNA damaging agents mitomycin C (a DNA interstrand cross-linking agent) and the fluoroquinolones norfloxacin, levofloxacin and moxifloxacin (topoisomerase inhibitors that causes double-strand breaks) induce transformation in Streptococcus pneumoniae (Claverys et al., 2006). Engelmoer and Rozen (2011) also showed, in Streptococcus pneumoniae, that transformation protects against the bactericidal effect of mitomycin C. In addition, induction of competence protects against the antibiotics streptomycin and kanamycin (Claverys et al., 2006; Engelmoer and Rozen, 2011). Although these aminoglycosides were, until recently, regarded as non-DNA damaging, work by Foti et al. (2012) in Escherichia coli suggests that a substantial portion of aminoglycoside bactericidal activity results from release of the hydroxyl radical $(\mathrm{OH} \bullet)$ and induction of DNA damages including double-strand breaks.

DNA damaging UV irradiation increases transformation in Bacillus subtilis (Michod et al., 1988). Ciprofloxacin, which interacts with DNA gyrase and introduces double-strand breaks, induces expression of competence genes in Helicobacter pylori, thus enhancing the frequency of transformation (Dorer et al., 2010). Charpentier et al. (2011) tested 64 toxic molecules to determine which of these induce competence in Legionella pneumophila. Only six of these, all DNA damaging agents, caused strong induction. These agents were mitomycin $C$ (which causes DNA inter-strand crosslinks), norfloxacin, ofloxacin and nalidixic acid [inhibitors of DNA gyrase that cause double-strand breaks (Albertini et al., 1995)], bicyclomycin [causes double-strand breaks (Washburn and Gottesman, 2011)], and hydroxyurea [causes oxidation of DNA bases (Sakano et al., 2001)]. UV irradiation also induced competence for transformation in Legionella pneumophila. Charpentier et al. (2011) suggested that competence for transformation probably evolved as a response to DNA damage.

The number of genome copies in logarithmically growing bacteria typically differ from the number of genomes in stationary phase bacteria, and this has implications for the capability of bacteria to carry out homologous recombinational repair (HRR). During logarithmic growth, two or more copies of any particular region of the chromosome are ordinarily present in a bacterial cell, as cell division is not precisely matched with chromosome replication. HRR is effective at repairing double-strand damages, such as double-strand breaks. This repair process depends on interaction of the damaged chromosome with a second homologous chromosome. During logarithmic growth, a DNA damage in one chromosome may be repaired by HRR using sequence information from the other homologous daughter chromosome. As bacterial cells approach stationary phase they typically have just one copy of the chromosome, and HRR requires input of an homologous template from another cell by transformation (Bernstein et al., 2012).

A series of experiments were carried out using Bacillus subtilis irradiated by UV light as the damaging agent to test whether the adaptive function of transformation is repair of DNA damages (for review, see Michod et al., 2008). The results of these experiments indicated that 
transforming DNA acts to repair potentially lethal DNA damages introduced by UV in the recipient DNA. The particular process responsible for repair was likely HRR.

In Nisseria gonorrhoeae, uptake of DNA during transformation depends on the presence of specific short nucleotide sequences (9-10mers residing in coding regions) in the donor DNA. These nucleotide sequences are called DNA uptake sequences (DUSs). DUSs occur at a particularly high density within genes involved in DNA repair, including HRR (Davidsen et al., 2004). Stohl and Seifert (2006) presented evidence that HRR mediated by the RecA protein plays an important role in protecting Neisseria gonorrhoeae against oxidative damage. Davidsen et al. (2004) suggested that the over-representation of DUSs in DNA repair genes may reveal the benefits of maintaining or restoring the integrity of the repair machinery through preferential uptake of genome maintenance genes that are especially important, and must be replaced by new copies if irreparably damaged or lost.

\section{The sexual cycle is induced by stress in single-celled and simple multicellular eukaryotes}

In eukaryotic microorganisms, sex occurs under stressful conditions as it does in bacteria. Among currently existing unicellular and simple multicellular eukaryotes, sexual reproduction is ordinarily facultative. These organisms usually reproduce asexually in a favorable environment, but reproduce sexually when under stress. Sex is induced in these organisms by starvation, mechanical damage, desiccation and heat shock. One example is the paramecium tetrahymena that can be induced to undergo conjugation (sexual mating) by starvation (Elliott and Hayes, 1953). Another example is the unicellular green alga Chlamydomonas reinhardi. When this organism is grown in a medium depleted of a source of nitrogen, vegetative cells differentiate into gametes (Sager \& Granik, 1954). These gametes are then able to fuse, form zygotes and undergo meiosis. A further example is the haploid fission yeast Schizosaccharomyces pombe. This yeast is a facultative sexual microorganism that can undergo mating when nutrients become limiting (Davey, 1998). The budding yeast Saccharomyces cerevisiae reproduces by mitosis as diploid cells when nutrients are abundant. However, when starved, this yeast undergoes meiosis to form haploid spores (Herskowitz, 1988). The oomycete Phytophthora cinnamomi is induced to undergo sexual reproduction by hydrogen peroxide or mechanical damage to hyphae (Reeves and Jackson, 1974). Sex, in the multicellular green algae Volvox carteri, is induced by heat shock (Kirk and Kirk, 1986).

\section{Meiosis is induced by DNA damaging conditions in microbial eukaryotes}

In sections 2 and 5, above, we reviewed evidence that sex was present early in the evolution of eukaryotes, raising the likelihood that eukaryotic sex arose from ancestral prokaryotic sex. We also reviewed evidence in section 9 that bacterial sex (transformation) is an adaptation for 
repair of DNA damages. In this section we present evidence that sex in eukaryotes, particularly the meiotic stage of the sexual cycle, is also an adaptation for response to DNA damage.

Hydrogen peroxide produces oxidative stress that causes a variety of DNA damages including modified bases and single- and double-strand breaks (Slupphang et al., 2003). When the yeast Schizosaccharomyces pombe was exposed to the oxidizing agent hydrogen peroxide, sex was induced (Bernstein and Johns, 1989). Mating and formation of sexual spores was increased by 4- to 18-fold upon exposure to hydrogen peroxide.

As mentioned in the preceding section, sex in the green algae Volvox carterei is induced by heat shock (Kirk and Kirk, 1986). This induction of sex is inhibited by anti-oxidants, indicating that heat shock induction of sex is mediated by oxidative stress (Nedelcu and Michod, 2003). Furthermore, Nedelcu et al. (2004) showed that an inhibitor of the mitochondrial electron transport chain, that induces oxidative stress, also induced sex in Volvox carteri. On the basis of this evidence Nedelcu and Michod (2003; 2004) suggested that reactive oxygen species produced by oxidative stress cause DNA damage leading to the induction of sex in Volvox carteri. Thus sex in Volvox carterei, as in Schizosaccharomyces pombe, appears to be an adaptation for coping with DNA damage induced by oxidative stress.

\section{Recombinational repair of DNA damages in the germ line}

Studies from a wide range of eukaryotes indicate that meiotic recombinational repair is an adaptation for repairing germ-line DNA damages. For example, exposure of eukaryotes to a DNA damaging agent causes increased meiotic recombination (expected as a result of HRR) as measured by exchange of allelic markers. Thus X-irradiation increases meiotic allelic recombination in Saccharomyces cerevisiae (Kelly et al., 1983) and in the nematode Caenorhabditis elegans (Kim and Rose, 1987). In the fruit fly Drosophila melanogaster, meiotic recombination is increased by UV light (Prudhommeau and Proust, 1973), gamma-rays (Suzuki and Parry, 1964) and mitomycin C (Schewe et al., 1971). These observations indicate that DNA damage increases homologous recombinational repair of the damage and this can be detected as increased allelic recombination.

In another type of experiment, Preston et al. (2006) studied the repair of double-strand breaks in the male germ line of Drosophila by the three repair processes of NHEJ (non-homologous end joining), SSA (single-strand annealing) and HR-h (homologous recombinational repair between non-sister homologs). They found that HR-h increased linearly in the germ line from $14 \%$ in young individuals to $60 \%$ in old ones, whereas the other pathways showed a corresponding decrease. The following explanation was offered for these findings. NHEJ and SSA are considered to be faster than HR-h and require no homologous template, but they are much more errorprone. Therefore NHEJ and SSA repair would be favored under conditions where the benefit of rapid gamete production outweighs the longer-term costs of inaccurate repair of DNA damage. The few individuals who survive to old age may occupy a less crowded environment where competition is decreased and opportunities to mate are rare. Under these conditions, the advantages of speed are negated and accurate HR-h repair becomes the favored strategy. 
In some protozoans, vitality declines over the course of successive asexual cell divisions by binary fission. However, if sexual interaction (conjugation) occurs, vitality is restored. Evidence indicates that meiosis leads to rejuvination, and that this rejuvenation is associated with removal of DNA damages. The ciliate protozoan Paramecium tetraurelia has a polyploid macronucleus that contains about 800 to 1500 copies of the genome, and a diploid micronucleus. The macronuclear DNA expresses cellular functions, and the micronucleus contains the germline DNA. Paramecium tetraurelia is a facultative sexual microorganism that can reproduce asexually by binary fission or by a sexual process involving meiosis. There are two kinds of meiotic process; the first is a kind of outcrossing sex called conjugation, and the second is a kind of self-fertilization called automixis. In the asexual growth phase, during which cell divisions are by mitosis rather than meiosis, a gradual loss of vitality occurs that is referred to as clonal aging. If an asexual line of clonally aging paramecia fails to undergo conjugation or automixis it will die out after about 200 fissions.

Auferheide (1987) clarified the cause of clonal aging in Paramecium tetraurelia by the use of transplantation experiments. When macronuclei of clonally young paramecia were injected into clonally older paramecia, the lifespan of the older recipients was prolonged. In contrast, when cytoplasm, rather than macronuclei, was transplanted from young to older paramecia the lifespan of the recipients was not prolonged. These experiments suggested that clonal lifespan is determined by the macronucleus rather than the cytoplasm. Subsequent experiments by Smith-Sonneborn (1979), Holmes and Holmes (1986) and Gilley and Blackburn (1994) demonstrated that clonal aging is associated with a dramatic increase in DNA damage. When clonally aged paramecia undergo meiosis, either in association with conjugation or automixis, the old macronucleus disintegrates and a new macronucleus is formed by replication of the micronuclear DNA that had just experienced meiosis followed by fertilization. These paramecia were rejuvenated in the sense of having a restored clonal lifespan. It thus appears that clonal aging is caused, in large part, by a progressive increase in DNA damage; and that rejuvination is due to repair of these damages in the micronucleus during meiosis and the reestablishment of the macronucleus by replication of the newly repaired micronuclear DNA.

A similar phenomenon to clonal aging in paramecium is also found in yeast. In the budding yeast Saccharomyes cerevisiae, mother cells give rise to progeny buds by mitotic division. Mother cells undergo replicative aging over successive generations and, ultimately, death. However when a mother cell undergoes meiosis and gametogenesis, lifespan is reset (Unal et al., 2011). The replicative potential of gametes (spores) formed by aged cells is the same as gametes formed by young cells, indicating that age-associated damage is removed from the aged mother cells. This observation suggests that during meiosis removal of age-associated damages leads to rejuvination, but it is not yet clear if these damages are actually in the DNA.

In the nematode Caenorhabditis elegans, oocyte nuclei in the pachytene stage of meiosis (the stage in which recombination occurs between non-sister homologs) are hyper-resistant to Xirradiation compared to oocytes in diakinesis (a later stage of meiosis) or early embryonic cells after fertilization (Takanami et al., 2000). Pachytene hyper-resistance depends on expression of gene $c e-r d h-51$, a homolog of yeast gene rad51 (recA-like) that catalyzes key steps in homologous recombinational repair. Furthermore, nuclei in the pachytene stage have greater resistance to heavy ion particle irradiation than nuclei in the later diplotene and diakinesis stages of meiosis, as well as nuclei in early embryonic cells (Takanami et al., 2003). Resistance 
during pachytene to heavy ion particle irradiation in Caenorhabditis elegans also depends on expression of gene $c e-r d h-51$, a rad51/rec $A$ homolog. In addition, this resistance also depends on gene ce-atl-1, a gene related to atm that is necessary for repair of double-strand breaks by homologous recombinational repair in mammals, and for fertility in mice and humans (Table 1). These observations indicate that Caenorhabditis elegans meiotic pachytene nuclei efficiently repair X-ray and heavy ion-induced DNA damage by homologous recombinational repair.

Coogan and Rosenblum (1988) measured the repair of double-strand damages after $\gamma$ irradiation of rat spermatogenic cells in sequential stages of germ cell formation (i.e. spermatagonia, preleptotene spermatocytes, pachytene spermatocytes and spermatid spermatocytes). The greatest repair capability occurred in pachytene spermatocytes, the meiotic stage in which recombinational repair occurs. These findings suggest that a function of meiosis, expressed during the pachytene stage, is the repair of double-strand damages. The most likely natural sources of the double-strand damages normally repaired at pachytene are reactive oxygen species generated by active metabolism.

Recombinational repair of DNA damages during meiosis also likely occurs in plants and depends on rad51, a recA ortholog. In Arabidopsis thaliana, mutants defective in a rad51 paralog, $x r c c 3$, are deficient in meiotic recombination and are sterile; they are also hypersensitive to mitomycin C, a DNA cross-linking agent (Bleuyard and White, 2004; Bleuyard et al., 2005). In rice (Oryza sativa), the rad51C gene is required for meiosis of both female and male gametocytes, and mutants deficient in this gene have increased sensitivity in somatic cells to the DNA alkylating agent methyl methanesulfonate and the cross-linking agent mitomycin C (Kou et al., 2012). In maize, mutants defective in homologs of rad51 are deficient in meiosis and are sterile; they also produce embryos that are highly susceptible to induction of double-strand breaks by radiation (Li et al., 2007).

The observations summarized in this section imply that meiosis is an adaptation for recombinational repair of DNA damages in the germ line.

\section{Unrepaired DNA damage during mammalian gametogenesis causes infertility}

In mammals, germ cells are exposed to natural causes of DNA damage. For instance, several germ cell stages, including pachytene spermatocytes, have the potential to produce levels of reactive oxygen species sufficient to cause oxidative stress (Fisher and Atkin, 1997). Reactive oxygen species can produce double-strand damages in DNA. Also, heat can cause DNA damage. Paul et al. (2008) showed that mild heat stress ( 40 or $42^{\circ} \mathrm{C}$ for 30 minutes) applied to the mouse scrotum causes DNA strand breaks in germ cells leading to infertility and abnormalities in embryonic development of progeny.

In the US, about $15 \%$ of all couples are infertile. A major cause of male infertility is oxidative stress during gametogenesis (Makker et al., 2009). Oxidative stress causes a variety of DNA damages including oxidized and ring fragmented bases and single- and double-strand breaks (Slupphang et al., 2003). Nili et al. (2011) showed that subfertile men have an increased 
frequency of sperm chromosomal aneuploidy as well as increased DNA damage (i.e. DNA strand breaks and alkali labile sites). Lewis and Aitken (2005) reviewed evidence that an increased level of DNA damage in the germ line of men is associated with poor semen quality, low rate of fertilization, impaired pre-implantation development, increased abortion, and a higher incidence of disease in progeny including childhood cancer. These authors also noted that the natural causes of this elevated DNA damage are unclear, but that the principal candidate is oxidative stress.

Genes whose products are employed in recombinational repair (e.g. atm, brca1, dmc1, mlh1, pms2, mlh5 and ercc1) are expressed at a substantially higher level in testes than in somatic cells of males, and inherited mutations in these genes cause infertility (Table 1).

\begin{tabular}{|c|c|c|c|}
\hline Genetic defect & $\begin{array}{l}\text { Mutant female and/or male } \\
\text { infertility }\end{array}$ & $\begin{array}{l}\text { Expression in testes of the } \\
\text { wild-type gene }\end{array}$ & References \\
\hline $\operatorname{atm}^{(+/-)}$ & $\begin{array}{l}\text { Females and males in both mice } \\
\text { and humans are infertile }\end{array}$ & $\begin{array}{l}\text { 4-fold increased mRNA } \\
\text { expression in human testes vs. } \\
\text { somatic cells }\end{array}$ & $\begin{array}{l}\text { Barlow et al., 1998; } \\
\text { Galetzka et al., } 2007\end{array}$ \\
\hline $\operatorname{brca} 1^{(--)}$ & $\begin{array}{l}\text { The few surviving male mice are } \\
\text { infertile }\end{array}$ & $\begin{array}{l}\text { 3-fold increased mRNA } \\
\text { expression in human testes vs. } \\
\text { somatic cells }\end{array}$ & $\begin{array}{l}\text { Cressman et al., 1999; } \\
\text { Galetzka et al., } 2007\end{array}$ \\
\hline$d m c 1^{(-/-)}$ & $\begin{array}{l}\text { Female and male mice are } \\
\text { infertile; } d m c^{(+-)} \text {women } \\
\text { undergo premature ovarian } \\
\text { failure }\end{array}$ & $\begin{array}{l}\text { Expression specific for } \\
\text { meiotic cells }\end{array}$ & $\begin{array}{l}\text { Pittman et al., 1998; } \\
\text { Mandon-Pepin et al., } 2008\end{array}$ \\
\hline$m / h 1^{(--)}$ & $\begin{array}{l}\text { Female and male mice are } \\
\text { infertile }\end{array}$ & $\begin{array}{l}\text { 1.7-fold increased mRNA } \\
\text { expression in human testes vs. } \\
\text { somatic cells }\end{array}$ & $\begin{array}{l}\text { Wei et al., 2002; } \\
\text { Galetzka et al., } 2007\end{array}$ \\
\hline $\begin{array}{l}\text { pms } 2^{(+/-)} \\
\text {or pms } 2^{(--)}\end{array}$ & $\begin{array}{l}\text { Male infertility and sperm DNA } \\
\text { damage }\end{array}$ & $\begin{array}{l}2 \text { to } 4 \text {-fold increased mRNA } \\
\text { expression in human testes vs. } \\
\text { somatic cells }\end{array}$ & $\begin{array}{l}\text { Galetzka et al., 2007; } \\
\text { Ji et al., } 2012\end{array}$ \\
\hline$m s h 5^{(--)}$ & $\begin{array}{l}\text { Female and male } m s h 5^{(--)} \\
\text {mice are infertile; women who } \\
\text { are } m s h 5^{(+-)} \\
\text {or } m s h 5^{(--)} \\
\text {undergo premature ovarian } \\
\text { failure }\end{array}$ & $\begin{array}{l}\text { Expression specific for } \\
\text { meiotic cells }\end{array}$ & $\begin{array}{l}\text { Edelmann et al., 1999; } \\
\text { Mandon-Pepin et al., } 2008\end{array}$ \\
\hline $\operatorname{ercc} 1^{(--)}$ & $\begin{array}{l}\text { Female and male mice are } \\
\text { infertile }\end{array}$ & $\begin{array}{l}\text { Expressed at a high level in } \\
\text { mouse testes }\end{array}$ & Hsia et al. (2003) \\
\hline
\end{tabular}

Table 1. The effect on fertility of mutations in genes employed in meiotic recombinational repair and the increased expression of these genes in testes 
In humans, the mismatch repair genes $m l h 1, p m s 2$ and $m s h 5$ participate in meiotic recombination. Variants of these genes that are common in human populations cause increased risk of male infertility (Ji et al., 2012). Also variants of $m l h 1$ and pms2 cause increased sperm DNA damage.

In women, about half of fertilized eggs fail to produce embryos that survive, as is typical of mammals generally (Austin, 1972). Roberts and Lowe (1975) estimated that about half of all post-implantation embryos are lost, often before the first missed period. Also, Wilcox et al. (1988) noted that, after implantation, about $31 \%$ of embryos miscarry, often before the woman is aware that she is pregnant. Although the basis for these malfunctions is not yet established, it is likely that unrepaired DNA damage is an important contributing factor. Adriaens et al. (2009) reviewed several studies showing that the mammalian oocyte can repair various kinds of DNA damage occurring either spontaneously or as a consequence of exposure to external agents. However these repair processes are not $100 \%$ efficient.

Chemotherapy used in cancer treatment can result in infertility in young female cancer survivors. Soleimani et al. (2011) showed that exposure to the chemotherapeutic agent doxorubicin causes massive double-strand breaks in human and rodent oocytes leading to apoptotic cell death. Activation of the recombinational repair pathway appeared to allow only a minority of oocytes to survive.

The inheritance of a mutant brca1 allele leading to heterozygosity $\left[b r c a 1^{(+/)}\right]$can dramatically increase a woman's life-time risk for developing breast cancer. The Brca1 protein has a key role in recombinational repair of DNA damages in somatic cells and in meiosis during oogenesis. Oktay et al. (2010) found that infertile women who are heterozygous for a brca1 mutation do not respond well to clinical treatments for enhancing fertility. This finding suggested that deficiency of Brca1 mediated recombinational repair during oogenesis reduces fertility.

Reproductive capacity of women begins to diminish after young adulthood (i.e. about age 37 years). Recently, Titus et al. (2013) showed that DNA double-strand breaks - a measure of DNA damage - accumulate with age in primordial follicles (immature primary oocytes) of mice and humans. Paralleling this increase in breaks, expression of key recombinational repair genes brca1, mre11, rad51 and atm declined in oocytes of mice and humans. In brca1-deficient mice $\left[\mathrm{brca}^{(+-)}\right]$, double-strand breaks increased, numbers of primordial follicles decreased and reproductive capacity declined relative to wild-type mice. Women with a brca1 mutation were also found to have a lower ovarian reserve. Using RNA interference in mouse oocytes, it was found that inhibition of expression of brca1, mre11, rad51 or atm increased double-strand breaks and decreased oocyte survival (Titus et al., 2013). These findings implicate deficient recombinational repair and consequent accumulation of DNA damages as important determinants of oocyte aging. Furthermore, Mandon-Pepin et al. (2008) showed that mutations in either of two genes that are active in meiotic recombinational repair ( $d m c 1$ and $m s h 5)$ are associated with loss of normal ovarian function in women younger than 40 years of age (Table 1).

The findings described in this section indicate that DNA damage during spermatogenesis and oogenesis can lead to infertility, a significant clinical problem for humans. Furthermore, 
meiotic recombinational repair likely plays an important role in repairing such DNA damages and avoiding infertility.

\section{Homologous recombinational repair functions similarly during meiosis and mitosis, but has greater scope for repairing double-strand damages during meiosis}

Homologous recombinational repair occurs during mitosis, but is largely limited to interaction between nearby sister-chromosomes subsequent to replication (but prior to cell division). During mitosis, the frequency of recombination between non-sister homologous chromosomes is only about $1 \%$ of that between sister-chromosomes (Moynahan and Jasin, 2010). In contrast, during meiosis, recombination between non-sister homologous chromosomes is frequent and is indeed a key characteristic of meiosis. Despite these differences concerning which homologous chromosomes are involved, the machinery of recombinational repair appears to be closely similar during mitosis and meiosis. Numerous common gene products are essential to both processes. The parallels in the machinery of recombinational repair across meiosis and mitosis in eukaryotes, and even extending to the mechanism of recombination during transformation in bacteria, suggests similarity of function.

In the budding yeast Saccharomyces cerevisiae, mutations in several genes needed for meiotic and mitotic recombination cause increased sensitivity to radiation and/or genotoxic chemicals (Haynes and Kunz, 1981). For instance, gene rad52 is required for both meiotic recombination (Game et al., 1980) and mitotic recombination (Malone and Esposito, 1980). Rad52 mutants have increased sensitivity to killing by X-rays, methylmethane sulfonate and the DNA crosslinking agent 8-methoxypsoralen-plus-UV light, and show reduced meiotic recombination (Haynes and Kunz, 1981; Henriques and Moustacchi, 1980; Game et al., 1980), suggesting that recombinational repair is needed for the repair of the different DNA damages caused by these agents.

Mutants of the fruit fly Drosophila melanogaster that are defective in the "meiotic genes" mei-41 and mei-9 have increased sensitivity to X-rays, UV, methylmethane sulfonate, nitrogen mustard, benzo(s)pyrene and 2-acetylaminofluorene, and are also defective in meiotic recombination (Baker et al., 1976; Boyd, 1978; Rasmusen, 1984). In addition, mutants defective in genes $h d m$ and DmRad51/spnA are deficient in meiotic recombination and also have increased sensitivity to X-rays or methylmethane sulfonate, (Joyce et al., 2009; Staeva-Viera et al., 2003) suggesting a deficiency in recombinational repair in somatic cells. Drosophila mutants defective in brca2 are also deficient in both meiotic and mitotic recombinational repair (Klovstad et al., 2008). Overall, mutants of Drosophila that are defective in genes essential for carrying out recombination (i.e. genes mei-41, mei-9, $h d m$, spnA and brca2) are more sensitive to killing by a variety of DNA damaging agents than are wild-type flies. This increased sensitivity is likely caused by a reduced capability of the somatic cells of the flies to perform recombinational repair of the DNA damages caused by these agents. These same mutants also 
have reduced meiotic recombination, indicating that they are likely deficient in homologous recombinational repair of DNA damages during meiosis.

Homologous recombinational repair during meiosis provides a unique advantage compared to mitosis. During meiosis, systematic pairing and recombination between non-sister homologous chromosomes is promoted compared to mitosis, where recombination between nonsisters chromosomes is infrequent (Moynahan and Jasin, 2010). Consequently, during mitosis, homologous recombinational repair is largely restricted to the portion of the cell cycle in which DNA replication is occurring (S phase) and after DNA replication is complete (G2 phase) so that a closely adjacent homologous chromosome is available. During this restricted period of the mitotic cell cycle, double-strand damages may be accurately removed by homologous recombinational repair between sister homologs (Tichy et al., 2010). However, during the portion of the mitotic cell cycle after cell division but prior to DNA replication (G1 phase), double-strand damages, such as double-strand breaks and interstrand crosslinks, are not ordinarily repaired by accurate homologous recombinational repair. Rather, they are either repaired by the inaccurate process of non-homologous end-joining that generates mutation, or else the double-strand damages cause cell death.

In contrast to the constraint on DNA repair during mitosis, during meiosis, homologous recombinational repair can accurately remove double-strand damages that arise at any stage of the cell cycle because of systematic pairing of non-sister homologous chromosomes. Cells in the G1 phase of meiosis are more resistant to the lethal effects of X-rays than cells in the G1 phase of mitosis (Kelley et al., 1983). This finding suggests that types of damages caused by Xrays, which include double-strand damages, are more readily repaired during meiotic G1 than mitotic G1. Repair capability during meiosis is likely more effective than during mitosis, because there is greater access to a homolog for the source of needed redundant information and also because the proteins that catalyze homologous recombinational repair are present at an increased level (Table 1).

In this section we reviewed evidence that DNA damages caused by a variety of exogenous agents are repaired by homologous recombinational repair during mitosis. Since this repair process is closely similar to the analogous process during meiosis, we infer that homologous recombination during meiosis also functions to repair a variety of DNA damages.

During each cell cycle in humans, 30,000 to 50,000 DNA replication origins are activated (Mechali, 2010). Thus chromosomes are replicated in segments. During pre-meiotic replication, a double-strand damage in any segment may block completion of replication of the segment until the damage is repaired. During the subsequent prophase I stage of meiosis when the blocked segment becomes paired with a non-sister homolog, the damage may be accurately repaired by recombinational repair using the intact information from the non-sister homolog. After the damage is removed, replication of the segment can be completed. Hence meiosis can provide a means for accurately repairing double-strand damages present in all stages of the preceding cell cycle. 


\section{The key role of RecA repair protein in bacterial transformation}

In this section we focus on the role of the RecA protein and its orthologs in catalyzing key steps of recombination during transformation. First, RecA interacts with ATP and single-stranded DNA to form a helical filament. This filament then binds to double-stranded DNA, searches for homology and next catalyses exchange with the complementary strand of the duplex DNA producing a new heteroduplex (Chen et al., 2008). Pairing of homologous regions of the two parental genomes leads to exchange of information between the genomes (recombination).

The RecA protein is essential for transformation in the bacteria Bacillus subtilis, Streptococcus pneumoniae and Neisseria gonorrhoeae (Dubnau et al., 1973; Martin et al., 1992; Claverys et al., 2009; Stohl et al., 2011). In Streptococcus pneumoniae expression of the recA gene is induced during development of competence (Mortier-Barriere et al., 1998). In Bacillus subtilis, expression of the recA gene is induced following DNA damage, as well as during development of the competent state (Cheo et al., 1992).

In Bacillus subtilis transformation, the RecA protein first interacts with several other competence proteins to form a multiprotein complex. This complex next interacts with incoming single-stranded DNA at a cell pole to prepare the entering DNA for recombination with the resident chromosome (Kidane and Graumann, 2005). The interaction of the single-stranded DNA with RecA protein leads to formation of striking filamentous structures that emanate from the cell pole harboring the competence machinery, and then extend further into the cytosol. Kidane and Graumann (2005) considered that these RecA/single-stranded DNA filamentous threads represent dynamic nucleofilaments that scan the chromosome for regions of homology. By this process, incoming DNA is brought to the homologous site in the bacterial chromosome where informational exchange occurs.

The molecular interactions of bacterial RecA protein with DNA were analyzed by Cox (1991; 1993) who concluded the RecA protein evolved as the central component of an homologous recombinational repair system for dealing with DNA damage. Cox concluded that DNA repair is the most important function of homologous genetic recombination. This conclusion is in accord with the idea that, in bacterial transformation, RecA protein functions to remove DNA damages in the resident chromosome by homologous recombinational repair using intact (undamaged) information from the donor chromosome. As noted above, bacteria typically become competent for transformation in late log phase, when most cells are haploid and the only available source of intact homologous DNA is another bacterium.

\section{The key role of RecA orthologs in eukaryotic meiosis}

In this section we present evidence that orthologs of the RecA protein have a similar role in eukaryotic meiosis to that in bacterial transformation, the facilitation of recombinational repair between two homologous DNA molecules of different parental origin. 
Protein components of the homologous recombination machinery appear to be highly conserved from bacteria to eukaryotes. We first consider unicellular, and then multicellular eukaryotes. Genes rad51 and $d m c 1$ of the yeasts Saccharomyces cerevisiae and Schizosaccharomyces pombe are orthologs of the bacterial $r e c A$ gene. The tertiary structure of the yeast Dmc1 recombinase is similar to the overall structure of the bacterial RecA recombinase (Story et al., 1993). In addition to yeast, the $d m c 1$ gene has also been identified in other unicellular eukaryotes, i.e. Giardia, Trypanosoma, Leishmania, Entamoeba and Plasmodium (Ramesh et al., 2005). The yeast Rad51 and Dmc1 proteins interact with single-stranded DNA to form a presynaptic filament that initiates recombinational repair (Sauvageau et al., 2005; San Filippo et al., 2008). This filament is similar to the RecA/single-stranded DNA nucleofilament, described above, that is formed during bacterial transformation. Whereas the Dmc1 recombinase only acts during meiosis, Rad51 acts both during meiosis and mitosis (Bugreev et al., 2011). Thus the Rad51 and Dmc1 recombinases that perform key steps in meiosis of unicellular eukaryotes appear to be structurally and functionally similar to the bacterial RecA recombinase that performs key steps of transformation in bacteria. This similarity suggests evolution of the sexual process of meiosis from the sexual process of transformation.

We next review evidence that orthologs of bacterial RecA play a key role in meiotic recombination in multicellular animals and plants, suggesting evolutionary continuity of the central role of recA orthologs in sexual processes from microorganisms to multicellular life forms.

Orthologs of the RecA protein play a key role in meiosis of animals (e.g. nematodes, mice and humans) and of plants (e.g. Arabidopsis, rice and lilies). In the nematode Caenorhabditis elegans, resistance to X-ray induced DNA damage in meiotic pachytene nuclei depends on the strongly expressed $r e c A$-like gene (ce-rdh-1) (Takenami et al., 2000), implying a key role of this gene in meiotic recombinational repair.

In the testis and ovary of the mouse, a homolog of the $\operatorname{rec} A$ and $\operatorname{rad} 51$ genes is expressed at a high level, suggesting that a RecA-like protein is employed in meiotic recombination in the mouse (Shinohara et al., 1993). In the mouse, mutations in the $d m c 1$ gene, which encodes the meiosis specific recombinase, cause an inability to complete meiosis, failure to undergo intimate pairing of homologous chromosomes, and sterility (Pittman et al., 1998; Yoshida et al., 1998; see Table 1). In humans, Dmc1 recombinase forms nucleoprotein complexes with single-stranded DNA that promote the search for homology and informational exchange reactions that are crucial steps of recombinational repair (Sehorn et al., 2004; Bugreev et al., 2005).

Rad51 and Dmc1, RecA-like recombinases, are required for meiosis in the plant Arabidopsis thaliana (Li et al., 2004; Couteau et al., 1999). In the lily, Rad51 and Lim15 (an ortholog of Dmc1) co-localize on meiotic prophase I chromosomes where they form discrete foci (Terasawa et al., 1995). The proteins of these foci are though to cooperate in the search for homology and the pairing of homologous sequences. Similarly, in rice an ortholog of Dmc1 promotes the pairing of homologous chromosomes and is required for meiosis (Deng and Wang, 2007). 


\section{Another key repair protein employed in both transformation and meiosis}

Prior to the assembly of the RecA recombinase or an equivalent ortholog recombinase on single-stranded DNA to form a presynaptic filament, a single-strand-binding protein [termed SSB in bacteria and RPA (replication protein A) in eukaryotes], processes the single-stranded DNA. Bacillus subtilis and Streptococcus pneumoniae encode a single-stranded DNA binding protein $(\mathrm{SsbB})$ that is expressed uniquely during competence for genetic transformation, and directly protects internalized donor single-stranded DNA (Attaiech et al., 2011). In Streptococcus pneumoniae, SsbB is highly abundant, and potentially could allow the binding of half a genome equivalent of DNA (Attaiech et al., 2011). SsbB participates in the processing of ssDNA into recombinants, and is of crucial importance for chromosomal transformation. Thus, in both transformation and meiosis, recombination depends on an analogous accessory protein, in addition to the RecA and RecA-like recombinases.

\section{Meiosis, sex and outcrossing}

The essential feature of meiosis is information exchange between two genomic DNA molecules derived from different individuals (parents). This feature is shared with bacterial transformation, which we have proposed here to be the ancestral precursor to meiosis. The two different individuals that participate in mating events leading to meiosis may be closely or distantly related to each other. When the two individuals are distantly related to each other they are likely to differ more genetically than if closely related. Thus in matings of distantly related individuals there is a greater potential for generating genetically varied progeny than in matings of closely related individuals.

Evolutionary biologists have often assumed that the potential benefit of producing genetically varied progeny is of substantially greater consequence than the advantage of DNA repair and is, by itself, sufficient to explain the adaptive advantage of meiosis specifically, and the adaptive benefit of sex generally. Critical evaluations of this view have been presented elsewhere (e.g. Bernstein et al., 1987; Birdsell \& Wills, 2003; Michod et al., 2008; Gorelick \& Heng, 2011; Horandl, 2009; Horandl, this volume). However, our view, in brief, is that genetic variation is a byproduct of homologous recombinational repair during meiosis, and that any benefit of producing varied progeny is a long-term population level effect that would supplement the advantage of DNA repair. DNA repair is an immediate benefit that occurs at each sexual generation. In the short term, the benefit of variation, we think, is unlikely to be adequate, by itself, to maintain sex, especially in those organisms where the costs of sex are high (see Michod et al., 2008; Horandl, this volume).

In many microbial eukaryotes, it is likely that, in nature, mating occurs most often between members of the same clonal population and that outcrossing is uncommon. For instance, Ruderfer et al. (2006) analyzed the ancestry of natural yeast Saccharomyces cereviae strains and concluded that outcrossing occurs only about once every 50,000 cell divisions. Mating is almost 
always between closely related yeast cells in nature. Mating occurs when haploid yeast cells of opposite mating type MATa and MAT $\alpha$ come into contact. Zeyl and Otto (2007) and Ruderfer et al. (2006) pointed out that such contacts are frequent between closely related yeast cells for two reasons. The first reason is that cells of opposite mating type are present together in close proximity in the same ascus (an ascus is the sac that contains the cells directly produced by a single meiosis). The second reason for frequent contact between closely related cells is that haploid Saccharomyces cerevisiae cells of one mating type, upon cell division, often produce daughter cells of the opposite mating type. Thus, in this yeast, it appears that under natural conditions meiotic events that produce negligible recombinational variation are vastly more common than meiotic events that do produce variation. The relative rarity of meiotic events that result from outcrossing and produce recombinational variation is consistent with the idea that the main adaptive function of meiosis is recombinational repair of DNA damage, since this benefit is realized at each meiosis whether or not outcrossing occurs. Furthermore it is difficult to comprehend how meiosis, a complex developmental process, could be maintained through natural selection during the 50,000 cell divisions between outcrossing events, if the primary benefit of meiosis were production of genetic variation.

Among early facultatively sexual eukaryotes, the requirement of sex that two different parental genomes come together in a common cytoplasm would have led to a brief diploid interval. However, these early facultatively sexual organisms were likely primarily haploid, reproducing asexually as haploid organisms and only experiencing diploidy transiently during sex. As eukaryotes evolved further, the diploid stage of the life cycle became more extended, and eventually became predominant as in present day mammals and higher plants. As the diploid stage increased in importance, outcrossing also became more important because genomes of distantly related individuals are less likely than genomes of related individuals to contain common mutations. Thus outcrossing allows the masking of expression of deleterious recessive mutations in the diploid stage (Bernstein et al., 1985; Bernstein et al., 1987; Birdsell and Wills, 2003). The mutual masking of deleterious recessive mutations is referred to as complementation, a phenomenon underlying such concepts as hybrid vigor, heterosis, avoidance of inbreeding depression, and the incest taboo. We consider that these advantages of outcrossing are secondary benefits of sexual reproduction that arose with the development of a significant diploid stage, and that the primary advantage has remained homologous recombinational repair of damages in the DNA to be passed on to progeny.

\section{Summary and conclusions}

In bacteria, transformation involves transfer of DNA from a donor bacterial cell to a recipient cell, and can be regarded as a primitive form of sex. Competence for transformation arises by a complex developmental process that requires expression of numerous bacterial genes. Therefore competence appears to be an evolved adaptation that is of substantial benefit to the bacterium. Competence ordinarily develops during exposure to stressful environmental 
conditions such as growth to high cell density and nutritional limitation. Such stress conditions tend to cause increased DNA damage. Studies of transformation in several different bacterial species indicate that transformation is an adaptive response to DNA damage, and that it functions to repair DNA through the process of homologous recombinational repair.

Eukaryotes emerged in evolution from prokaryotic ancestors over 1.5 billion years ago. Based on recent evidence, meiosis, and thus sexual reproduction, appears to have arisen very early in the evolution of eukaryotes. Transformation and meiotic sex both involve the coming together of DNA molecules from separate individuals, recombination between these molecules, and passage of the recombined DNA to progeny. Thus transformation and meiosis are similar at a fundamental level. This similarity suggests that meiotic sex evolved from ancestral prokaryotic sex, that is, from bacterial transformation. In extant eukaryotic microorganisms sex is generally facultative and tends to occur under stressful conditions that are similar to the conditions that induce competence for transformation in bacteria. Also in extant eukaryotic microorganisms, sex is induced by agents that cause DNA damage. Damage to the genome (DNA in most species) appears to be a fundamental problem for life. In multicellular eukaryotes, defective recombinational repair during meiosis causes infertility that is likely due to accumulation of excessive DNA damages.

The RecA protein catalyzes key steps in recombination during bacterial transformation. Orthologs of RecA (e.g. Rad51 and Dmc1 proteins) in eukaryotes catalyze similar steps in recombination during meiosis. The RecA protein and its orthologs interact with singlestranded DNA to form a presynaptic nucleofilament that initiates recombination. This nucleofilament is thought to scan the partner chromosome for regions of homology in preparation for the informational exchange reactions of homologous recombinational repair. Other proteins that interact with the RecA protein or its orthologs also seem to carry out similar functions in transformation and meiosis. These similarities in the machinery of recombinational repair during transformation and meiosis suggest continuity in the evolution of sexual processes through the prokaryote to eukaryote boundry.

As the early eukaryotes evolved from their prokaryote ancestors, the diploid phase of the sexual cycle became increasingly prominent compared to the haploid phase. With the increasing prominence of diploidy, avoidance of expression of deleterious recessive mutations in diploid cells became advantageous. The two individuals that participate in a mating may be either distantly or closely related. A consequence of outcrossing, the mating of distantly related individuals, is that deleterious recessive mutations occurring in one parent are not likely to occur in the other, and so the expression of deleterious mutations tend to be masked in the progeny's diploid cells. This mutual masking of deleterious recessive mutations is referred to as complementation, a phenomenon that underlies hybrid vigor. In contrast, closely related individual are likely to share the same deleterious recessive mutations, and matings between them are more likely to lead to expression of deleterious recessive mutations in progeny. Thus, adaptations have evolved to promote outcrossing. Outcrossing organisms are also more likely to produce genetically varied progeny than inbreeding individuals and this also may provide advantages over time at the population level. 


\section{Author details}

Harris Bernstein and Carol Bernstein*

*Address all correspondence to: bernstein324@yahoo.com

Department of Cellular and Molecular Medicine, College of Medicine, University of Arizona, Tucson, Arizona, USA

\section{References}

[1] Adriaens, I., Smitz, J. \& Jacquet, P. (2009). The current knowledge on radiosensitivity of ovarian follicle development stages. Human Reproduction Update, Vol. 15(3), pp. 359-377.

[2] Akamatsu, T. \& Taguchi, H. (2001). Incorporation of the whole chromosomal DNA in protoplast lysates into competent cells of Bacillus subtilis. Bioscience, Biotechnology, and Biochemistry, Vol. 65(4), pp. 823-829.

[3] Akopyants, N.S., Kimblin, N., Secundino, N., Patrick, R., Peters, N., Lawyer, P., Dobson, D.E., Beverley, S.M. \& Sacks, D.L. (2009). Demonstration of genetic exchange during cyclical development of Leishmania in the sand fly vector. Science, Vol. 324, pp. 265-268.

[4] Albertini, S., Chételat, A.A., Miller, B., Muster, W., Pujadas, E., Strobel, R. \& Gocke, E. (1995). Genotoxicity of 17 gyrase- and four mammalian topoisomerase II-poisons in prokaryotic and eukaryotic test systems. Mutagenesis, Vol. 10(4), pp. 343-351.

[5] Ames, B.N., Shigenaga, M.K. \& Hagen, T.M. (1993). Oxidants, antioxidants, and the degenerative diseases of aging. Proceedings of the National Academy of Sciences USA, Vol. 90(17), pp. 7915-7922.

[6] Anagnostopoulos, C. \& Spizizen, J. (1961). Requirements for transformation in Bacillus subtilis. Journal of Bacteriology, Vol. 81, pp. 741-746.

[7] Aspiras, M.B., Ellen, R.P. \& Cvitkovitch, D.G. (2004). ComX activity of Streptococcus mutans growing in biofilms. FEMS Microbiology Letters, Vol. 238(1), pp. 167-174.

[8] Attaiech, L., Olivier, A., Mortier-Barriere, I., Soulet, A.-L., Granadel, C., Martin, B., Polard, P. \& Claverys, J.-P. (2011). Role of the single-stranded DNA-binding protein SsbB in Pneumococcal transformation: Maintenance of a reservoir for genetic plasticity. PLoS Genetics, Vol. 7(6), pp. 1-12.

[9] Aufderheide, K.J. (1987). Clonal aging in Paramecium tetraurelia. II. Evidence of functional changes in the macronucleus with age. Mechanisms of Ageing and Development, Vol. 37, pp. 265-279. 
[10] Austin, C.R. (1972). Pregnancy losses and birth defects. In: Austin, C.R., Short, R.V. editors. Reproduction in Mammals. Book 2, Chapter 5, London: Cambridge University Press, p. 134.

[11] Baker, B.S., Boyd, J.B., Carpenter, A.T.C., Green, M.M., Nguyen, T.D., Ripoll, P. \& Smith, P.D. (1976). Genetic controls of meiotic recombination and somatic DNA metabolism in Drosophila melanogaster. Proceedings of the National Academy of Sciences USA, Vol. 73(11), pp. 4140-4144.

[12] Barlow, C., Liyanage, M., Moens, P.B., Tarsounas, M., Nagashima, K., Brown, K., Rottinghaus, S., Jackson, S.P., Tagle, D., Ried, T. \& Wynshaw-Boris, A. (1998). Atm deficiency results in severe meiotic disruption as early as leptonema of prophase I. Development, Vol. 125, pp. 4007-4017.

[13] Bell, J.C., Plank, J.L., Dombrowski, C.C. \& Kowalczykowski, S.C. (2012). Direct imaging of RecA nucleation and growth on single molecules of SSB-coated ssDNA. Nature, Vol. 491(7423), pp. 274-278.

[14] Bernstein C., \& Johns, V. (1989). Sexual reproduction as a response to $\mathrm{H}_{2} \mathrm{O}_{2}$ damage in Schizosaccharomyces pombe. Journal of Bacteriology, Vol. 171(4), pp. 1893-1897.

[15] Bernstein, C., Bernstein, H., Payne, C.M. \& Garewal, H. (2002). DNA repair/proapoptotic dual-role proteins in five major DNA repair pathways: fail-safe protection against carcinogenesis. Mutation Research, Vol. 511, pp. 145-178.

[16] Bernstein, C \& Bernstein, H. (2004). Aging and sex, DNA repair in. In: Encyclopedia of Molecular Cell Biology and Molecular Medicine, Vol. 1, R.A. Meyers, ed., pp. 53-98, Wiley-VCH, Weinheim.

[17] Bernstein H., Byerly, H.C., Hopf, F.A. \& Michod, R.E. (1985). Genetic damage, mutation, and the evolution of sex. Science, Vol. 229, pp.1277-1281.

[18] Bernstein, H., Hopf, F.A. \& Michod, R.E. (1987). The molecular basis of the evolution of sex. Advances in Genetics, Vol. 24, pp. 323-370.

[19] Bernstein, H. \& Bernstein, C. (2010). Evolutionary origin of recombination during meiosis. BioScience, 60(7), 498-435.

[20] Bernstein, H., Bernstein, C. \& Michod, R.E. (2011). Meiosis as an evolutionary adaptation for DNA repair. In: DNA Repair, Kruman, I., ed., InTech Publ. Rijeka, Croatia, Chapter 19, pp. 357-382.

[21] Bernstein, H., Bernstein C. \& Michod, R.E. (2012). DNA repair as the primary adaptive function of sex in bacteria and eukaryotes. In: DNA Repair: New Research. Nova Science Publishers, New York, Chapter 1: pp. 1-49.

[22] Bertani, G. \& Baresi, L. (1987). Genetic transformation in the methanogen Methanococcus voltae PS. Journal of Bacteriology, Vol. 169(6), pp. 2730-2738. 
[23] Birdsell, J.A. \& Wills, C. (2003). The evolutionary origin and maintenance of sexual recombination: A review of contemporary models. In: Evolutionary Biology. R.G. MacIntyre, M.T. Clegg, (Eds.), pp. 27-138. Kluwer Academic/Plenum Publishers.

[24] Bleuyard, J.Y. \& White, C.I. (2004). The Arabidopsis homologue of Xrcc3 plays an essential role in meiosis. The EMBO Journal, Vol. 23, pp. 439-449.

[25] Bleuyard, J.Y., Gallego, M.E., Savigny, F. \& White, C.I. (2005). Differing requirements for the Arabidopsis Rad51 paralogs in meiosis and DNA repair. The Plant Journal, Vol. 41, pp. 533-545.

[26] Boussau, B., Karlberg, E.O., Frank, A.C., Legault, B.A. \& Andersson, S.G. (2004). Computational inference of scenarios for alpha-proteobacterial genome evolution. Proceedings of the National Academy of Sciences USA, Vol. 101(26), pp. 9722-9727.

[27] Boyd, J.B. (1978). DNA repair in Drosophila. In: Hanawalt, P.C., Friedberg, E.C., Fox, C.F., editors. DNA Repair Mechanisms. New York: Academic Press, pp. 449-452.

[28] Bray, C.M. \& West, C.E. (2005). DNA repair mechanisms in plants: crucial sensors and effectors for the maintenance of genome integrity. New Phytologist, 168(3), pp. 511-528.

[29] Bugreev, D.V., Golub, E.I., Stasiak, A.Z., Stasiak, A. \& Mazin, A.V. (2005). Activation of human meiosis-specific recombinase Dmc1 by $\mathrm{Ca}^{2+}$. Journal of Biological Chemistry, Vol. 280(29), pp. 26886-26895.

[30] Bugreev, D.V., Pezza, R.J., Mazina, O.M., Voloshin, O.N., Camerini-Otero, R.D. \& Mazin, A.V. (2011). The resistance of DMC1 D-loops to dissociation may account for the DMC1 requirement in meiosis. Nature Structural and Molecular Biology, Vol. 18(1), pp. 56-61.

[31] Butterfield, N.J. (2000). Bangiomorpha pubescens n. gen., n. sp.: implications for the evolution of sex, multicellularity, and the Mesoproterozoic/Neoproterozoic radiation of eukaryotes. Paleobiology, Vol. 26(3), pp. 386-404.

[32] Charpentier, X., Kay, E., Schneider, D., \& Shuman, H.A. (2011). Antibiotics and UV radiation induce competence for natural transformation in Legionella pneumophila. Journal of Bacteriology, Vol. 193(5), pp. 1114-1121.

[33] Cheah, K.S.E. \& Osborne, D.J. (1978). DNA lesions occur with loss of viability in embryos of ageing rye seed. Nature, Vol. 272, pp. 593-599.

[34] Chen, I. \& Dubnau D. (2004). DNA uptake during bacterial transformation. Nature Reviews/Microbiology, Vol. 2(3), pp. 241-249.

[35] Chen, Z., Yang, H. \& Pavletich, N.P. (2008). Mechanism of homologous recombination from RecA-ssDNA/dsDNA structures. Nature, Vol. 453, pp. 489-496. 
[36] Cheo, D.L., Bayles, K.W. \& Yasbin, R.E. (1992). Molecular characterization of regulatory elements controlling expression of the Bacillus subtilis rec $A^{+}$gene. Biochimie, Vol. 74, pp. 755-762.

[37] Claverys, J.P., Prudhomme, M. \& Martin, B. (2006). Induction of competence regulons as a general response to stress in gram-positive bacteria. Annual Review of Microbiology, Vol. 60, pp. 451-475.

[38] Claverys, J.P., Martin, B., \& Polard, P. (2009). The genetic transformation machinery: composition, localization and mechanism. FEMS Microbiology Reviews, Vol. 33, pp. 643-656.

[39] Cline, S.W., Schalkwyk, L.C. \& Doolittle, W.F. (1989). Transformation of the archaebacterium Halobacterium volcanii with genomic DNA. Journal of Bacteriology, Vol. 171(9), pp. 4987-4991.

[40] Coogan, T.P. \& Rosenblum, I.Y. (1988). DNA double-strand damage and repair following -irradiation in isolated spermatogenic cells. Mutation Research, Vol. 194, pp. 183-191.

[41] Cooper, M.A., Adam, R.D., Worobey, M. \& Sterling, C.R. (2007). Population genetics provides evidence for recombination in Giardia. Current Biology, Vol. 17, pp. 1984-1988.

[42] Couteau, F., Belzile, F., Horlow, C., Grandjean, O., Vezon, D. \& Doutriaux, M.P. (1999). Random chromosome segregation without meiotic arrest in both male and female meiocytes of a dmc1 mutant of Arabidopsis. The Plant Cell, Vol. 11, pp. 1623-1634.

[43] Cox, C.J., Foster, P.G., Hirt, R.P., Harris, S.R. \& Embley, T.M. (2008). The archaebacterial origin of eukaryotes. Proceedings of the National Academy of Sciences USA, Vol. 105(51), pp. 20356-20361.

[44] Cox, M.M. (1991). The RecA protein as a recombinational repair system. Molecular Microbiology, Vol. 5(6), pp. 1295-1299.

[45] Cox, M.M. (1993). Relating biochemistry to biology: How the recombinational repair function of RecA protein is manifested in its molecular properties. BioEssays, Vol. 15(9), 617-623.

[46] Cox, P.A. (1988). Hydrophilous pollination. Annual Review of Ecology and Systematics, Vol. 19, pp. 261-279.

[47] Cressman, V.L., Backlund, D.C., Avrutskaya, A.V., Leadon, S.A., Godfrey, V. \& Koller, B.H. (1999). Growth retardation, DNA repair defects, and lack of spermatogenesis in BRCA1-deficient mice. Molecular and Cellular Biology, Vol. 19(10), pp. 7061-7075.

[48] Dacks, J. \& Roger, A.J. (1999). The first sexual lineage and the relevance of facultative sex. Journal of Molecular Evolution, Vol. 48, pp. 779-783.

[49] Davey, J. (1998). Fusion of a fission yeast. Yeast, Vol. 14, pp.1529-1566. 
[50] Davidsen, T., Rodland, E.A., Lagesen, K., Seeberg, E., Rognes, T. \& Tonjum, T. (2004). Biased distribution of DNA uptake sequences towards genome maintenance genes. Nucleic Acids Research, Vol. 32(3), pp. 1050-1058.

[51] De Bont, R., \& van Larebeke, N. (2004). Endogenous DNA damage in humans: a review of quantitative data. Mutagenesis, Vol. 19(3), pp.169-185.

[52] Demaneche, S., Kay, E., Gourbiere, F. \& Simonet, P. (2001). Natural transformation of Pseudomonas fluorescens and Agrobacterium tumefaciens in soil. Applied and Environmental Microbiology, Vol. 67(6), pp. 2617-2621.

[53] Deng, Z.Y., \& Wang, T. (2007). OsDMC1 is required for homologous pairing in Oryza sativa. Plant Molecular Biology, Vol. 65, 31-42.

[54] Dorer, M.S., Fero, J. \& Salama, N.R. (2010). DNA damage triggers genetic exchange in Helicobacter pylori. PloS Pathogens, Vol. 6(7), pp. 1-10. e1001026

[55] Dubnau, D., Davidoff-Abelson, R., Scher, B. \& Cirigliano, C. (1973). Fate of transforming deoxyribonucleic acid after uptake by competent Bacillus subtilis: phenotypic characterization of radiation-sensitive recombination-deficient mutants. Journal of Bacteriology, Vol. 114(1), pp. 273-286.

[56] Edelmann, W., Cohen, P.E., Kneitz, B., Winand, N., Lia, M., Heyer, J., Kolodner, R., Pollard, J.W. \& Kucherlapati, R. (1999). Mammalian mutS homologue 5 is required for chromosome pairing in meiosis. Nature Genetics, Vol. 21, pp. 123-127.

[57] Elliott, A.M. \& Hayes, R.E. (1953). Mating types in tetrahymena. Biological Bulletin, Vol. 105, pp. 269-284.

[58] Engelmoer, D.J.P. \& Rozen, D.E. (2011). Competence increases survival during stress in Streptococcus pneumoniae. Evolution, Vol. 65-12, pp. 3475-3485.

[59] Fisher, H.M. \& Aitken, R.J. (1997). Comparative analysis of the ability of precursor germ cells and epididymal spermatozoa to generate reactive oxygen metabolites. The Journal of Experimental Zoology, Vol. 277, pp. 390-400.

[60] Foti, J. J., Devadoss, B., Winkler, J.A., Collins, J.J. \& Walker, G.C. (2012). Oxidation of the guanine nucleotide pool underlies cell death by bactericidal antibiotics. Science, Vol. 336, pp. 315-319.

[61] Fraga, C.G., Shigenaga, M.K., Park, J.W., Degan, P. \& Ames, B.N. (1990). Oxidative damage to DNA during aging: 8-hydroxy-2'-deoxyguanosine in rat organ DNA and urine. Proceedings of the National Academy of Sciences USA, Vol. 87(12), pp. 4533-4537.

[62] Frols, S., Ajon, M., Wagner, M., Teichmann, D., Zolghadr, B., Folea, M., Boekema, E.J., Driessen, A.J.M., Schleper, C. \& Albers, S-V. (2008). UV-inducible cellular aggregation of the hyperthermophilic archaeon Sulfolobus solfataricus is mediated by pili formation. Molecular Microbiology, Vol. 70(4), pp. 938-952. 
[63] Frols, S., White, M.F. \& Schleper, C. (2009). Reactions to UV damage in the model archaeon Sulfolobus solfataricus. Biochemical Society Transactions, Vol. 37(1), 36-41.

[64] Gabaldon, T. \& Huynen, M.A. (2003). Reconstruction of the proto-mitochondrial metabolism. Science, Vol. 301, p. 609.

[65] Galetzka, D., Weis, E., Kohlschmidt, N., Bitz, O., Stein, R. \& Haaf, T. (2007). Expression of somatic DNA repair genes in human testes. Journal of Cellular Biochemistry, Vol. 100, pp. 1232-1239.

[66] Game, J.C., Zamb, T.J., Braun, R.J., Resnick, M. and Roth, R.M. (1980). The role of radiation (rad) genes in meiotic recombination in yeast. Genetics, Vol. 94, pp. 51-68.

[67] Gilley, D. \& Blackburn, E.H. (1994). Lack of telemere shortening during senescence in Paramecium. Proceedings of the National Academy of Sciences USA, Vol. 91, 1955-1958.

[68] Goodgal, S.H. \& Herriott, R.M. (1961). Studies on transformations of Hemophilus influenzae. I. Competence. Journal of General Physiology, Vol. 44, pp. 1201-1227.

[69] Gorelick, R. \& Heng, H.H.Q. (2011). Sex reduces genetic variation: A multidisciplinary review. Evolution, Vol. 65(4), pp. 1088-1098.

[70] Gray, M.W., Burger, G. \& Lang, B.F. (1999). Mitochondrial evolution. Science Vol. 283, pp. 1476-1481.

[71] Gross, J. \& Bhattacharya, D. (2010). Uniting sex and eukaryote origins in an emerging oxygenic world. Biology Direct, Vol. 5:53, pp. 1-20.

[72] Haber, J.E. (1999). DNA recombination: the replication connection. Trends Biochem Sci Vol. 24(7), pp. 271-275.

[73] Halary, S., Malik, S.-B., Lildhar, L., Slarnovits, C.H., Hijri, M., \& Corradi, N. (2011). Conserved meiotic machinery in Glomus spp., a putatively ancient asexual fungal lineage. Genome Biology and Evolution, Vol. 3, pp. 950-958.

[74] Haynes, R.H. (1988). Biological context of DNA repair. In: Friedberg, E.C. \& Hanawalt, P.C., editor, Mechanisms and Consequences of DNA Damage Processing, New York, Alan R. Liss, pp. 577-584.

[75] Haynes, R.H. \& Kunz, B.A. (1981). DNA repair and mutagenesis in yeast. In: Strathern, J; Jones, E; Broach, J, editors. The Molecular Biology of the Yeast Saccharomyces. Life Cycle and Inheritance. Cold Spring Harbor, N.Y., Cold Spring Harbor Laboratory, 371-414.

[76] Helbock, H.J., Beckman, K.B., Shigenaga, M.K., Walter, P.B., Woodall, A.A., Yeo, H.C. \& Ames, B.N. (1998). DNA oxidation matters: the HPLC-electrochemical detection assay of 8-oxo-deoxyguanosine and 8-oxo-guanine. Proceedings of the National Academy of Sciences USA, Vol. 95(1), pp. 288-293. 
[77] Henriques, J.A.P. \& Moustacchi, E. (1980). Sensitivity to photoaddition of mono- and bifunctional furocoumarins of X-ray sensitive mutants of Saccharomyces cerevisiae. Photochemistry and Photobiology, Vol. 31, pp. 557-563.

[78] Herskowitz, I. (1988). Life cycle of the budding yeast Saccharomyces cerevisiae. Microbiological Reviews, Vol. 52(4), pp. 536- 553.

[79] Hoeijmakers, J.H.J. (2009). DNA damage, aging, and cancer. New England Journal of Medicine, Vol. 361(15), pp. 1475-1485.

[80] Holmes, G.E. \& Holmes, N.R. (1986). Accumulation of DNA damages in aging Paramecium tetraurelia. Molecular and General Genetics, Vol. 204, pp. 108-114.

[81] Holthausen, J.T., Wyman, C. \& Kanaar, R. (2010). Regulation of DNA strand exchange in homologous recombination. DNA Repair (Amst), Vol. 9(12), pp.1264-1272.

[82] Horandl, E. (2009). A combinational theory for maintenance of sex. Heredity, Vol. 103, pp. $445-457$.

[83] Hsia, K.T., Millar, M.R., King, S., Selfridge, J., Redhead, N.J., Melton, D.W. \& Saunders, P.T.K. (2003). DNA repair gene Ercc1 is essential for normal spermatogenesis and oogenesis and for functional integrity of germ cell DNA in the mouse. Development Vol. 130, pp. 369-378.

[84] Javaux, E.J., Knoll, A.H. \& Walter, M.R. (2001). Morphological and ecological complexity in early eukaryote ecosystems. Nature, Vol. 412, pp. 66-69.

[85] Ji, G., Long, Y., Zhou, Y., Huang, C., Gu, A. \& Wang, X. (2012). Common variants in mismatch repair genes associated with increased risk of sperm DNA damage and male infertility. BMC Medicine, 10(49), pp. 1-10.

[86] Johnsborg, O., Eldholm, V. \& Håvarstein, L.S. (2007). Natural genetic transformation: prevalence, mechanisms and function. Research in Microbiology, Vol. 158(10), pp. 767-778.

[87] Johnson, A. (2003). The biology of mating in Candida albicans. Nature Reviews/Microbiology, Vol. 1, pp. 106-116.

[88] Joyce, E.F., Tanneti, S.N. \& McKim, K.S. (2009). Drosophila Hold'em is required for a subset of meiotic crossovers and interacts with the DNA repair endonuclease complex subunits MEI-9 and ERCC1. Genetics, Vol. 181, pp. 335-340.

[89] Kathe, S.D., Shen, G.P. \& Wallace, S.S. (2004). Single-stranded breaks in DNA but not oxidative DNA base damages block transcriptional elongation by RNA polymerase II in HeLa cell nuclear extracts. Journal of Biological Chemistry, Vol. 279(18), pp. 18511-18520.

[90] Kelly, S.L., Merrill, C. \& Parry, J.M. (1983). Cyclic variations in sensitivity to X-irradiation during meiosis in Saccharomyces cerevisiae. Molecular and General Genetics, Vol. 191, pp. 314-318. 
[91] Kidane, D. \& Graumann, P.L. (2005). Intracellular protein and DNA dynamics in competent Bacillus subtilis cells. Cell, Vol. 122, pp. 73-84.

[92] Kim, J.S. \& Rose, A.M. (1987). The effect of gamma radiation on recombination frequency in Caenorhabditis elegans. Genome, Vol. 29, pp. 457-462.

[93] Kirk, D.L. \& Kirk, M.M. (1986). Heat shock elicits production of sexual inducer in Volvox. Science, Vol. 231(4733), pp. 51-54.

[94] Klovstad, M., Abdu, U. \& Schupbach, T. (2008). Drosophila brca2 is required for mitotic and meiotic DNA repair and efficient activation of the meiotic recombination checkpoint. PloS Genetics, 4(2): e31.doi:10.1371/journal.pgen.0040031.

[95] Koppen, G. \& Verschaeve, L. (2001). The alkaline single-cell gel electrophoresis/ comet assay: a way to study DNA repair in radicle cells of germinating Vicia faba. Folia Biol. (Praha), Vol. 47(2), pp. 50-54.

[96] Kou, Y., Chang, Y., Li, X., Xiao, J. \& Wang, S. (2012). The rice RAD51C gene is required for the meiosis of both female and male gametocytes and the DNA repair of somatic cells. Journal of Experimental Botany, Vol. 63(14), pp. 5323-5335.

[97] Lahr, D.J.G., Parfrey, L.W., Mitchell, E.A.D., Katz, L.A. \& Lara, E. (2011). The chastity of amoebae: re-evaluating evidence for sex in amoeboid organisms. Proceedings of the Royal Society B: Biological Sciences. Published online 23 March 2011. doi:10.1098/rspb. 2011.0289

[98] Lewis, S.E.M. \& Aitken, R.J. (2005). DNA damage to spermatozoa has impacts on fertilization and pregnancy. Cell Tissue Research, Vol. 322, pp. 33-41.

[99] Li, J., Harper, L.C., Golubovskaya, I., Wang, C.R., Weber, D., Meeley, R.B., McElver, J., Bowen, B., Cande, W.Z. \& Schnable, P.S. (2007). Functional analysis of maize RAD51 in meiosis and double-strand break repair. Genetics, Vol. 176, pp. 1469-1482.

[100] Li, W., Chen, C., Markmann-Mulisch, U., Timofejeva, L., Schmeizer, E., Ma, H. \& Reiss, B. (2004). The Arabidopsis AtRAD51 gene is dispensable for vegetative development but required for meiosis. Proceedings of the National Academy of Sciences USA, Vol. 101(29), pp. 10596-10601.

[101] Lin, Z. Kong, H., Nei, M. \& Ma, H. (2006). Origins and evolution of the RecA/RAD51 gene family: Evidence for ancient gene duplication and endosymbiotic gene transfer. Proceedings of the National Academy of Sciences USA, Vol. 103(27), pp. 10328-10333.

[102] Makker, K., Agarwal, A. \& Sharma, R. (2009). Oxidative stress \& male infertility. Indian Journal of Medical Research, Vol. 129, pp. 357-367.

[103] Malik, S-B., Pightling, A.W., Stefaniak, L.M., Schurko, A.M. \& Logsdon, J.M. Jr. (2008). An expanded inventory of conserved meiotic genes provides evidence for sex in Trichomonas vaginalis. Plos One, Vol. 3(8): e2879. doi:10.1371/journal.pone.0002879. 
[104] Malone, R.E. \& Esposito, R.E. (1980). The RAD52 gene is required for homothallic interconversion of mating types and spontaneous mitotic recombination in yeast. Proceedings of the National Academy of Sciences USA, Vol. 77(1), pp. 503-507.

[105] Mandon-Pepin, B., Touraine, P., Kuttenn, F., Derbois, C., Rouxel, A., Matsuda, F., Nicolas, A., Cotinot, C. \& Fellous, M. (2008). Genetic investigation of four meiotic genes in women with premature ovarian failure. European Journal of Endocrinology, Vol. 158, pp. 107-115.

[106] Martin, B., Ruellan, J.M., Angulo, J.F., Devoret, R., and Claverys, J.P. (1992). Identification of the recA gene of Streptococcus pneumoniae. Nucleic Acids Research, Vol. 20(23), p. 6412 .

[107] Mechali, M. (2010). Eukaryotic DNA replication origins: many choices for appropriate answers. Nature Reviews: Molecular Cell Biology, Vol. 11, pp. 728-738.

[108] Michod, R.E., Wojciechowski, M.F. \& Hoelzer, M.A. (1988). DNA repair and the evolution of transformation in the bacterium Bacillus subtilis. Genetics, Vol. 118(1), pp. 31-39.

[109] Michod, R.E., Bernstein, H. \& Nedelcu, A.M. (2008). Adaptive value of sex in microbial pathogens. Infection, Genetics and Evolution, Vol. 8(3), pp. 267-285.

[110] Mortier-Barriere, I., de Saizieu, A., Claverys, J.P. \& Martin, B. (1998). Competencespecific induction of recA is required for full recombination proficiency during transformation in Streptococcus pneumoniae. Molecular Microbiology, Vol. 27(1), pp. 159-170.

[111] Moynahan, M.E. \& Jasin, M. (2010). Mitotic homologous recombination maintains genomic stability and suppresses tumorigenesis. Nature Reviews/ Molecular Cell Biology, Vol. 11, pp. 196-207.

[112] Muller, M. \& Martin, W. (1999). The genome of Rickettsia prowazekii and some thoughts on the origin of mitochondria and hyrogenosomes. BioEssays, Vol. 21, pp. 377-381.

[113] Murayama, Y., Kurokawa, Y., Mayanagi, K. \& Iwasaki, H. (2008). Formation and branch migration of Holliday junctions mediated by eukaryotic recombinases. Nature, Vol. 451(7181), pp. 1018-1021.

[114] Nakamura, J., Walker, V.E., Upton, P.B., Chiang, S.Y., Kow, Y.W. \& Swenberg, J.A. (1998). Highly sensitive apurinic/apyrimidinic site assay can detect spontaneous and chemically induced depurination under physiological conditions. Cancer Research, Vol. 58(2), pp. 222-225.

[115] Nedelcu, A.M. \& Michod, R.E. (2003). Sex as a response to oxidative stress: The effect of antioxidants on sexual induction in a facultatively sexual lineage. Proceedings of the Royal Society London B (suppl.) Vol. 270, pp. S136-S139. 
[116] Nedelcu, A.M., Marcu, O. \& Michod, R.E. (2004). Sex as a response to oxidative stress: a two-fold increase in cellular reactive oxygen species activates sex genes. Proceedings of the Royal Society London B, Vol. 271, pp. 1591-1596.

[117] Nili, H.A., Mozdarani, H. \& Pellestor, F. (2011). Impact of DNA damage on the frequency of sperm chromosomal aneuploidy in normal and subfertile men. Iranian Biomedical Journal, 15(4), 122-129.

[118] O'Connor, M., Wopat, A. \& Hanson, R.S. (1977). Genetic transformation in Methylobacterium organophilum. Journal of General Microbiology, Vol. 98, pp.265-272.

[119] Oktay, K., Kim, J. Y. Barad, D. \& Babayev, S.N. (2010). Association of BRCA1 mutations with occult primary ovarian insufficiency: A possible explanation for the link between infertility and breast/ovarian cancer risks. Journal of Clinical Oncology, Vol 28(2), pp. 240-244.

[120] Patel, G.B., Nash, J.H.E., Agnew, B.J. \& Sprott, G.D. (1994). Natural and electroporation-mediated transformation of Methanococcus voltae protoplasts. Applied and Environmental Microbiology, Vol. 60(3), pp. 903-907.

[121] Paul, C., Murray, A.A., Spears, N. \& Saunders, P.T. (2008). A single, mild, transient scrotal heat stress causes DNA damage, subfertility and impairs formation of blastocysts in mice. Reproduction, Vol. 136(1), pp. 73-84.

[122] Pittman, D.L., Cobb, J., Schimenti, K.J., Wilson, L.A., Cooper, D.M., Brignull, E., Handel, M.A. \& Schimenti, J.C. (1998). Meiotic prophase arrest with failure of chromosome synapsis in mice deficient for Dmc1, a germline-specific $\operatorname{Rec} A$ homolog. Molecular Cell, Vol. 1, pp. 697-705.

[123] Preston, C.R., Flores, C. \& Engels, W.R. (2006). Age-dependent usage of doublestrand-break repair pathways. Current Biology, Vol. 16, pp. 2009-2015.

[124] Prudhommeau, C. \& Proust, J. (1973). UV irradiation of polar cells of Drosophila melanogaster embryos. V. A study of the meiotic recombination in females with chromosomes of different structure. Mutation Research, Vol. 22, pp. 63-66.

[125] Raina, J.L. \& Modi, V.V. (1972). Deoxyribonucleate binding and transformation in Rhizobium japonicum. Journal of Bacteriology, Vol. 111(2), pp. 356-360.

[126] Ramesh, M.A., Malik, S.B. \& Logsdon, J.M. (2005). A phylogenomic inventory of meiotic genes: Evidence for sex in Giardia and an early eukaryotic origin of meiosis. Current Biology, Vol. 15, pp. 185-191.

[127] Rasmusen, A. (1984). Effects of DNA-repair-deficient mutants on somatic and germ line mutagenesis in the UZ system of Drosophila melanogaster. Mutation Research, Vol. 141, pp. 29-33.

[128] Reeves, R.J. \& Jackson, R.M. (1974). Stimulation of sexual reproduction in Phytophthora by damage. Journal of General Microbiology, Vol. 84, pp. 303-310. 
[129] Roberts, C.J. \& Lowe, C.R. (1975). Where have all the conceptions gone? Lancet, Vol. 305(7905), pp. 498-499.

[130] Rosenshine, I., Tchelet, R. \& Mevarech, M. (1989). The mechanism of DNA transfer in the mating system of an archaebacterium. Science, Vol. 245(4924), pp. 1387-1389.

[131] Ruderfer, D.M., Pratt, S.C., Seidel, H.S. \& Kruglyak, L. (2006). Population genomic analysis of outcrossing and recombination in yeast. Nature Genetics, Vol. 38(9), 1077-1081.

[132] Sagan, C. (1973). Ultraviolet selection pressure on the earliest organisms. Journal of Theoretical Biology, Vol. 39, pp. 195-200.

[133] Sager, R. \& Granick, S. (1954). Nutritional control of sexuality in Chlamydomonas reinhardi. Journal of General Physiology, Vol. 37, pp.729-742.

[134] Saito, Y., Taguchi, H. \& Akamatsu, T. (2006). Fate of transforming bacterial genome following incorporation into competent cells of Bacillus subtilis: a continuous length of incorporated DNA. Journal of Bioscience and Bioengineering, Vol. 101(3), pp. 257-262.

[135] Sakai, A., Nakanishi, M., Yoshiyama, K. \& Maki, H. (2006). Impact of reactive oxygen species on spontaneous mutagenesis in Escherichia coli. Genes to Cells, Vol. 11, pp. 767-778.

[136] Sakano, K., Oikawa, S., Hasegawa, K \& Kawanishi, S. (2001). Hydroxyurea induces site-specific DNA damage via formation of hydrogen peroxide and nitric oxide. Japanese Journal of Cancer, Vol. 92(11), pp. 1166-1174.

[137] Sandler, S.J., Satin, L.H., Samra, H.S. \& Clark, A.J. (1996). recA-like genes from three archaean species with putative protein products similar to Rad51 and Dmc1 proteins of the yeast Saccharomyces cerevisiae. Nucleic Acids Research, Vol. 24(11), 2125-2132.

[138] San Filippo, J., Sung, P. \& Klein, H. (2008). Mechanism of eukaryotic homologous recombination. Annual Review of Biochemistry, Vol. 77, pp. 229-257.

[139] Sauvageau, S., Stasiak, A.Z., Banville, I., Ploquin, M. Stasiak, A. \& Masson, J.Y. (2005). Fission yeast Rad51 and Dmc1, two efficient DNA recombinases forming helical nucleoprotein filaments. Molecular and Cellular Biology, Vol. 25(11), pp. 4377-4387.

[140] Schewe, M.J., Suzuki, D.T. \& Erasmus, U. (1971). The genetic effects of mitomycin C in Drosophila melanogaster. II. Induced meiotic recombination. Mutation Research, Vol. 12 , pp. 269-279.

[141] Sehorn, M.G., Sigurdsson, S., Bussen, W., Unger, V.M. \& Sung, P. (2004). Human meiotic recombinase Dmc1 promotes ATP-dependent homologous DNA strand exchange. Nature, Vol. 429, pp. 433-437.

[142] Shinohara, A., Ogawa, H., Matsuda, Y., Ushio, N., Ikeo, K. \& Ogawa, T. (1993). Cloning of human, mouse and fission yeast recombination genes homologous to RAD51 and recA. Nature Genetics, Vol. 4, pp. 239-243. 
[143] Slupphaug, G., Kavli, B. \& Krokan, H.E. (2003). The interacting pathways for prevention and repair of oxidative DNA damage. Mutation Research, Vol. 531, pp. 231-251.

[144] Smith-Sonneborn, J. (1979). DNA repair and longevity assurance in Paramecium tetraurelia. Science, Vol. 203, pp. 1115 - 1117.

[145] Soleimani, R., Heytens, E., Darzynkiewicz, Z. \& Oktay, K. (2011). Mechanisms of chemotherapy-induced human ovarian aging: double strand DNA breaks and microvascular compromise. Aging, Vol. 3(8), pp. 1-12.

[146] Solomon, J.M. \& Grossman, A.D. (1996). Who's competent and when: regulation of natural genetic competence in bacteria. Trends in Genetics, Vol. 12(4), pp.150-155.

[147] Staeva-Vieira, E., Yoo, S. \& Lehmann, R. (2003). An essential role of DmRad51/SpnA in DNA repair and meiotic checkpoint control. The EMBO Journal, Vol. 22(21), pp. 5863-5874.

[148] Stohl, E.A., Gruenig, M.C., Cox, M.M. \& Seifert, H.S. (2011). Purification and characterization of the RecA protein from Neisseria gonorrhoeae. PloS ONE, 6(2), e17101.

[149] Stohl, E.A. \& Seifert, H.S. (2006). Neisseria gonorrhoeae DNA recombination and repair enzymes protect against oxidative damage caused by hydrogen peroxide. Journal of Bacteriology, Vol. 188(21), pp. 7645-7651.

[150] Story, R.M., Bishop, D.K., Kleckner, N. \& Steitz, T.A. (1993). Structural relationship of bacterial RecA proteins to recombination proteins from bacteriophage T4 and yeast. Science, Vol. 259(5103), pp. $1892-1896$.

[151] Suzuki, D.T. \& Parry, D.M. (1964). Crossing over near the centromere of chromosome 3 in Drosophila melanogaster females. Genetics, Vol. 50, pp. 1427-1432.

[152] Takanami, T., Mori, A., Takahashi, H. \& Higashitani, A. (2000). Hyper-resistance of meiotic cells to radiation due to a strong expression of a single RecA-like gene in Caenorhabditis elegans. Nucleic Acids Research, Vol. 28(21), pp. 4232-4236.

[153] Takanami, T., Zhang, Y., Aoki, H., Abe, T., Yoshida, S., Takahashi, H., Horiuchi, S. \& Higashitani, A. (2003). Efficient repair of DNA damage induced by heavy ion particles in meiotic prophase I nuclei of Caenorhabditis elegans. Journal of Radiation Research, Vol. 44, pp. 271-276.

[154] Terasawa, M., Shinohara, A., Hotta, Y., Ogawa, H. \& Ogawa, T. (1995). Localization of RecA-like recombination proteins on chromosomes of the lily at various meiotic stages. Genes and Development, Vol. 9, pp. 925-934.

[155] Tice, R.R. \& Setlow, R.B. (1985). DNA repair and replication in aging organisms and cells. In: Finch, E.E. \& Schneider, E.L. (eds.) Handbook of the Biology of Aging. Van Nostrand Reinhold, New York. pp. 173-224.

[156] Tichy, E.D., Pillai, R., Deng, L., Liang, L., Tischfield, J., Schwemberger, S.J., Babcock, G.F. \& Stambrook, P.J. (2010). Mouse embryonic stem cells, but not somatic cells, pre- 
dominantly use homologous recombination to repair double-strand breaks. Stem Cells and Development, Vol. 19(11), pp. 1699-1711.

[157] Titus, S., Li, F., Stobezki, R., Akula, K., Unsal, E., Jeong, K., Dickler, M., Robson, M., Moy, F., Goswami, S. \& Oktay, K. (2013). Impairment of BRCA1-related DNA double-strand break repair leads to ovarian aging in mice and humans. Science Translational Medicine, Vol. 5(172ra21), pp. 1-12.

[158] Unal, E., Kinde, B. \& Amon, A. (2011). Gametogenesis eliminates age-induced cellular damage and resets life span in yeast. Science, Vol. 332, pp. 1554-1557.

[159] Vilenchik, M.M. \& Knudson, A.G. (2003). Endogenous DNA double-strand breaks: production, fidelity of repair, and induction of cancer. Proceedings of the National Academy of Sciences USA, Vol. 100(22), pp. 12871-12876.

[160] Washburn, R.S. \& Gottesman, M.E. (2011). Transcription termination maintains chromosome integrity. Proceedings of the National Academy of Sciences USA, Vol. 108(2), pp. 792-797.

[161] Wei, K., Kucherlapati, R. \& Edelmann, W. (2002). Mouse models for human DNA mismatch-repair gene defects. TRENDS in Molecular Medicine, Vol. 8(7), pp. 346-353.

[162] Wilcox, A.J., Weinberg, C.R., O'Connor, J.F., Baird, D.D., Schlatterer, J.P., Canfield, R.E., Armstrong, E.G. \& Nisula, B.C. (1988). Incidence of early loss of pregnancy. New England Journal of Medicine, Vol. 319(4), pp. 189-194.

[163] Wood, E.R., Ghane, F. \& Grogan, D.W. (1997). Genetic responses to the thermophilic archaeon Sulfolobus acidocaldarius to short-wavelength UV light. Journal of Bacteriology, Vol. 179(18), pp. 5693-5698.

[164] Worrell, V.E., Nagle, D.P., McCarthy, D. \& Eisenbraun, A. (1988). Genetic transformation system in the archaebacterium Methanobacterium thermoautotrophicum Marburg. Journal of Bacteriology, Vol. 170(2), pp. 653-656.

[165] Yoshida, K., Kondoh, G., Matsuda, Y., Habu, T., Nishimune, Y. \& Morita, T. (1998). The mouse $r e c A$-like gene $d m c 1$ is required for homologous chromosome synapsis during meiosis. Molecular Cell, Vol. 1, pp. 707-718.

[166] Zeyl, C.W. \& Otto, S.P. (2007). A short history of recombination in yeast. Trends in Ecology and Evolution, Vol. 22(5), pp. 223-225. 
